NBER WORKING PAPER SERIES

\title{
INSTITUTIONS, CAPITAL CONSTRAINTS AND ENTREPRENEURIAL FIRM DYNAMICS: EVIDENCE FROM EUROPE
}

\author{
Mihir Desai \\ Paul Gompers \\ Josh Lerner \\ Working Paper 10165 \\ http://www.nber.org/papers/w10165
NATIONAL BUREAU OF ECONOMIC RESEARCH
1050 Massachusetts Avenue
Cambridge, MA 02138
December 2003

We thank Bryan Lincoln, Eric Nierenberg, and Maria Raga for research assistance. Harvard Business School's Division of Research provided financial assistance. All errors are our own. The views expressed herein are those of the authors and not necessarily those of the National Bureau of Economic Research.

(C)2003 by Mihir Desai, Paul Gompers, and Josh Lerner. All rights reserved. Short sections of text, not to exceed two paragraphs, may be quoted without explicit permission provided that full credit, including (C) notice, is given to the source. 
Institutions, Capital Constraints and Entrepreneurial Firm Dynamics: Evidence from Europe Mihir Desai, Paul Gompers, and Josh Lerner

NBER Working Paper No. 10165

December 2003

JEL No. L1, G3

\section{$\underline{\text { ABSTRACT }}$}

We explore the impact of the institutional environment on the nature of entrepreneurial activity across Europe. Political, legal, and regulatory variables that have been shown to impact capital market development influence entrepreneurial activity in the emerging markets of Europe, but not in the more mature economies of Europe. Greater fairness and greater protection of property rights increase entry rates, reduce exit rates, and lower average firm size. Additionally, these same factors also associated with increased industrial vintage - a size-weighted measure of age - and reduced skewness in firm-size distributions. The results suggest that capital constraints induced by these institutional factors impact both entry and the ability of firms to transition and grow, particularly in lesser-developed markets.

Mihir Desai

Graduate School of Business

Harvard University

Soldiers Field

Boston, MA 02163

and NBER

mdesai@hbs.edu
Paul Gompers

Graduate School of Business

Harvard University

Soldiers Field

Boston, MA 02163

and NBER

pgompers@hbs.edu
Josh Lerner

Graduate School of Business

Harvard University

Soldiers Field

Boston, MA 02163

and NBER

josh@hbs.edu 


\section{Introduction}

The factors that foster the creation and growth of new enterprises remain of central interest to scholars and policy-makers. New enterprises are considered vital to economic growth and are increasingly important laboratories for scholars interested in settings where a variety of market frictions - informational asymmetry, moral hazard, and liquidity constraints, for example - are most amplified. At the same time, renewed interest in how differing institutional environments impact the functioning of capital markets and the investment behavior of firms has drawn attention to how economic institutions vary around the world and how they influence economic growth and firm behavior.

In this paper, we integrate these literatures by analyzing how institutional environments impact the entrepreneurial environment. In doing so, we analyze a variety of measures of entrepreneurial activity including traditional measures such as rates of entry, rates of exit, and average firm size as well as more comprehensive measures such as industrial vintage and the skewness of firm-size distributions. These measures of entrepreneurial activity are analyzed throughout Europe by exploiting a comprehensive database of firms that includes a variety of private, smaller firms. The European sample allows us to analyze a setting where there exists rich institutional variation (both between Western and Central and Eastern Europe (CEE) and amongst countries in those regions) and where comparable data is also available. Employing industry fixed effects in this setting further allows us to control for factors associated with distinctive industrial patterns across Europe. 
The results in the paper suggest that the institutional environment plays an important role in shaping the nature of industrial activity and, particularly, the dynamics of new enterprises. Specifically, greater fairness and protection of property rights is shown to increase rates of entry, decrease rates of exit, and lower average firm size. These effects, however, are not equally pronounced in all parts of Europe. The CEE region is characterized by particular sensitivity to institutional factors suggesting that these effects may be second-order in more mature, developed economies.

Industrial vintage and the skewness of firm-size distributions are also influenced by the institutional variables. In contrast to the results on average firm size, vintage (a sizeweighted measure of age) increases with greater fairness, with particularly strong relationships in the CEE. In conjunction with the results on size, entry and exit, these results suggest that greater fairness alters not only firm starts but also their ability to graduate into older, larger enterprisess. Greater fairness appears to reduce firm size but increase vintage, suggesting that fairness both makes it easier to start firms, but also makes it easier for firms to graduate into older, larger firms.

We also examine the skewness of firm size distributions across the CEE and Western Europe. Both the overall level of skewness and the relative skewness of firm-size distributions for younger firms appear to be a function of fairness and protection of property rights with particularly amplified effects in the CEE. These results are consistent with capital constraints leading to skewness in firm-size distributions, with the relative importance of these factors being greater in emerging markets. Institutional factors influence both firm entry and growth at later points. 
The paper proceeds as follows. Section 2 links this paper to the relevant literatures on financial constraints, the nature of entrepreneurial activity, and the cross-country variation in institutions. Section 3 motivates the empirical approach and describes the various variables employed in the subsequent analysis. Section 4 presents the analysis of institutional variables on the various characterizations of entrepreneurial activity. Section 5 is the conclusion.

\section{Motivation and Research Design}

Our examination of how institutional conditions determine the pattern of industrial activity draws on the existing literatures on financial constraints, the nature of entrepreneurial activity, and the new institutional economics literature. This section briefly reviews these works.

\subsection{Financial Constraints Literature}

The examination of financial constraints has been an important topic within corporate finance. Models such as Myers (1977), Townsend (1979), Stiglitz and Weiss (1981), and Myers and Majluf (1984) point to factors in the financial markets that may limit a firm's ability to raise outside capital. This inability to raise capital may stem from information gaps or an inability to contract on the outcomes of a venture. In this environment, good projects may find it impossible to get financing on reasonable terms. Positive net present value projects may, in this setting, be forgone. These works also demonstrates that firms prefer to finance investment with internal funds because it is less costly than external funds. Graham and Harvey (2001) show that this type of pecking 
order appears to figure largely in the minds of chief financial officers when they arrive at investment decisions.

Early empirical work on financial constraints explored the investment behavior of firms and its sensitivity to changes in internally generated funds. Fazzari, Hubbard, and Petersen (1988) found that firms with low or no dividend payout ratios were more likely to have investment that was sensitive to changes in free cash flow. The authors interpret their results as demonstrating that capital constraints likely affect companies that do not pay dividends as they forego investment when internal cash is not available. Costly external finance has been explored in multi-divisional firms and has been shown to play an important role as well. Lamont (1997) looks at companies that have oil related production and non-oil related businesses. He finds that investment in the non-oil related businesses are dramatically affected by swings in the world price of oil. This is true despite the fact that the firm's non-oil businesses were largely uncorrelated with the prospects for their oil businesses. Similarly, Shin and Stulz (1998) show that the investment in minor divisions of multi-segment firms is affected by the operating performance of the larger divisions even if the investment opportunity sets in each division are unrelated to each other.

Other types of investment activity have also been explored in the literature on capital rationing. Fazzari and Petersen (1993) find that low dividend payout firms have higher sensitivities of working capital investment to cash flow. Similarly, Himmelberg and Petersen (1994) show that small manufacturing firms have R\&D spending that is highly dependent upon operating cash flow. The research on capital rationing has been extended to other countries as well. Hoshi, Kayshap, and Scharfstein (1991) find that 
firms that are not part of a keiretsu have investment that is more sensitive to cash flows than are member firms in which member banks can provide credit. Devereux and Schiatarelli (1990) find a similar pattern for small firms in the United Kingdom. Small firms have investment-cash flow sensitivities that are greater than large firms. While most of this work has been done in developed markets, capital constraints are perhaps even more likely in developing and transition economies.

\subsection{Entrepreneurial Activity Research}

Entrepreneurial activity has received considerable attention in the economics literature. The empirical work on the determinants of entrepreneurial activity is largely focused on two streams of research. One body of work examines patterns of entry and exit. The other stream focuses on the dynamics of firm growth. Our research effort utilizes insights from both these streams of literature and combines the insights from work on the importance of capital constraints discussed above. Given the nature of information and uncertainty for entrepreneurial entities, new ventures have the potential for the greatest asymmetric information and the largest restrictions on their access to capital.

A large body of industrial organization work has explored the dynamics of firm entry and exit. In a series of papers, Dunne, Roberts, and Samuelson (1988, 1989) examine the changing participants in four-digit U.S. manufacturing industries, highlighting the heterogeneity of the rate of exit and entry across industries and the evolution of these rates over time. These papers document the rapid pace of entry during the early phases of a particular industry and that these rapid entry rates are also associated with rapid exit rates. 
Another set of studies has focused on individuals' transitions into self-employment (e.g., Evans and Leighton (1989), Holtz-Eakin, Joulfaian, and Rosen (1994a, 1994b)), with particular emphasis on the influence of capital constraints on these decisions. These papers show that the availability of personal capital is positively related to an individual's choice to become an entrepreneur. In addition, they show that entrepreneurs who have greater "exogenous" resources (via an inheritance, for example) are more likely to survive. The authors interpret these results as implying that credit constraints are a critical factor in both the founding and survival of new firms.

A third area of the entry and exit literature, most closely associated with Steven Klepper (e.g., Klepper and Graddy (1990), Klepper and Simons (2000)), has examined the empirical regularities associated with the changes in the number of firms active in an industry over time. Over time the number of firms increases, reaches a peak, and then declines as the industry consolidates. Most of this research does not examine the foundations of entry and exit rates across various industries or markets, rather explores the time series changes within an industry over time. The results point to the importance of controlling for industry in any examination of entry and exit. Country-level entry and exit rates may vary considerably, but much of this variation could be due to the cross sectional composition of industries active in those markets.

A second theme of entrepreneurial research examines the determinants of firm growth. Much of this literature has centered on the question of whether Gibrat's law holds: i.e., the proposition that firm growth is independent of firm size. As Sutton (1997) details, this proposition is equivalent to firm-size distributions being approximately 
lognormal. While initial studies (e.g., Simon and Bonnini (1958), Mansfield (1962)) were quite positive about the possibility of such a relationship, later work with more detailed data sets has taken a more skeptical view. A variety of studies, including Evans (1987), Hall (1987), and Davis, Haltiwanger, and Schuh (1996), show that growth rates and size are inversely related.

These works have inspired a number of theorists to develop depictions of the evolution of industry dynamics. In models such as Lucas (1978), Jovanovic (1982), Jovanovic and MacDonald (1994), and Ericson and Pakes (1995), the basic empirical patterns are explained through such factors as gradual learning by entrepreneurs and/or firms about their own ability and the nature of technological innovation in emerging industries.

More recently, capital constraints have been offered as an explanation for the pattern in the size distribution of firms and the relation between size and growth. Cooley and Quadrini (2003) examine violations of Gibrat's law. They develop a model of financial frictions and investment. They are able to show that capital constraints can potentially explain why small firms pay lower dividends, are more highly levered, have higher Tobin's q, invest more, and have investments that are more sensitive to cash flows.

Cabral and Mata (2003) develop a model of firm growth that depends upon investments and access to capital. Their model predicts that in the presence of capital constraints, the firm size distribution will be skewed. As capital constraints worsen, firmsize distributions will become more skewed. The intuition behind their result is that small firms with good investment opportunities may be periodically unable to raise the resources 
to exploit those opportunities. In that case, they will underinvest and grow slower than larger firms with internal cash flow to fund their projects. They argue that the distribution of firm size will be more highly skewed for younger firms because they are more likely to be capital rationed. Cabral and Mata then explore the firm size distribution in a sample of Portuguese manufacturing firms. They find that the distribution of firm size is indeed skewed and that the skewness is greater for younger firms.

Surprisingly few studies have sought to examine the patterns across nations in industry structure. Many of these studies (e.g., Johnson and Loveman (1995)) have faced challenges due to the limited number of industries and nations for which consistent data could be found. Moreover, many of these studies have been focused on finding common trends rather than explaining the diversity of patterns. There are, however, some interesting recent exceptions. Davis and Henrekson (1999) employ micro-data from the U.S. and Sweden. Another recent exception is Kumar, Rajan, and Zingales (1999), who look at average firm size and the dispersion in firm size across industries in 15 European nations. In particular, they explore the role that legal environment plays on firm size in capital intensive and non-capital intensive industries.

\subsection{Research on Legal and Institutional Regimes}

Our paper also draws upon the legal and institutional framework of recent papers in the field of law and economics. Much of this work has focused on the role that the institutional and legal regimes play on the development and functioning of capital markets. In particular, work by La Porta, et al. $(1998,2000)$ and La Porta, Lopez-de-Silanes, and Shleifer (1999) has examined legal and institutional factors that influence the breadth and 
depth of capital markets. These papers find that higher levels of corruption and better functioning legal environments promote greater development of financial markets. In addition, the legal and institutional factors and the overall level of capital market development, in turn, have been shown to influence aggregate economic outcomes as in King and Levine (1993), Rajan and Zingales (1998), and Demirguc-Kunt and Maksimovic (1998). The presumed channel for the impact of these variables is through the failure to allocate capital to firms with worthy investment opportunities as a consequence of the design of legal rules. Capital constraints are more likely to affect younger, more entrepreneurial firms in these environments.

In a related literature, the nature of property rights and the prevalence of corruption have been shown to influence the nature of investment and overall level of economic growth as in Knack and Keefer (1995). Studies at the micro level have been more limited, but Frye and Shleifer (1997) and Shleifer (1997), for example, show how variations in guarantees for property rights protection vary within formerly Communist countries and how this variation results in differing levels of entrepreneurial investment. As noted in the survey evidence provided in Johnson, McMillan and Woodruff (2002), the nature of property rights and the presence of external finance are distinct channels for how institutional variables impact economic outcomes. Again, these effects are likely to be more pronounced in developing and transition economies.

\section{Empirical Framework}

Our paper examines the role of capital constraints on entrepreneurial activity across 33 European countries. We look at the effect of country-level variation in economic, legal, 
and institutional variables on a variety of measures of the importance of entrepreneurial firm dynamics. These variables have been shown to have important effects on the development and functioning of capital markets. Our approach is to examine a variety of measures that provide insights into various dimensions of new firm activity. In particular, our unit of observation is at the country/industry level. Analyzing the determinants of entrepreneurial activity across Europe at the country/industry level holds the promise of controlling for industrial heterogeneity in a setting where technologies are relatively homogenous yet where there is variation in institutional regimes and there is a sharp difference in the stage of development between Western Europe and Central and Eastern Europe.

\subsection{Measures of Entrepreneurial Activity}

For each industry within a country, we calculate the entry and exit rate, the average firm size, the industrial vintage (a weighed-average measure of firm age discussed in detail below), and the skewness of the firm size distribution. In this section, we first discuss the dependent variables in our analysis and then describe the set of control variables that we employ.

\subsubsection{Firm Entry and Exit}

Firm entry and exit are important measures of entrepreneurial activity. Markets that provide an opportunity for greater numbers of startup firms are said to be more dynamic and entrepreneurial. Similarly, the rate at which firms die measures both the competitive nature of the local market and the potential advantage that incumbents have. 
We measure entry relative to the number of firms existing in the prior year. Our measure of entry is the number of firms that enter our sample in 1998 that were not in the sample in 1997 divided by the total number of firms that existed in 1997 in the country/industry pair. Similarly, we calculate the exit rate as the number of firms that were in our sample in 1997, but were not in 1998, divided by the total number of firms in that country/industry pair in 1997.

We expect that if capital constraints influence the entry decision, then more developed capital markets will provide greater access to capital and hence have greater entry rates. Institutional and legal variables associated with capital market development should be positively related to entry rates. Similarly, the literature on startup survival shows that reductions in capital constraints improve firm survival. We therefore would expect that political and legal variables associated with greater capital market development would lead to a lower exit rate.

\subsubsection{Average Firm Size}

Because of the role small firms play in an economy, we also look at average firm size. While this measure does not distinguish between small, old firms and small, young firms, it does measure whether the local economic environment supports a large number of small firms. Within each country/industry pair, we calculate the average firm size as measured by number of employees. While the prediction is not unambiguous, we might expect that lower levels of capital rationing would lead to greater number of small firms that can enter and survive in the market. Hence, average firm size would be expected to be smaller in markets with better economic institutions. 


\subsubsection{Industrial Vintage}

In addition to the more traditional measures discussed above, we are also interested in the importance of entrepreneurial firms for overall economic activity. In order to capture the importance of younger firms to industrial activity, we construct a measure of industrial vintage. Vintage is constructed within each country/industry pair and is the weighted average age of the firms in each industry where the weights are given by turnover, assets, or employees. In essence, this measure shows how important young firms are to the productive capacity of an industry. A high average vintage would imply that most of the productive capacity is produced by relatively older firms in the economy. On the other hand, a low vintage would indicate that young firms dominate the productive capacity. While the results are not sensitive to the choice of weights, we emphasize weighting by employees given the ability of this measure to obviate any accounting differences across countries.

How is vintage distinct from average firm size and why might these two measures of industrial activity diverge in their response to institutional factors? In particular, given that we expect younger firms to be smaller, won't economies or industries that are on average smaller also have a younger vintage? The distinction between the two measures can be best understood by considering the ways in which they are constructed:

$$
\text { Average Size }=\frac{\sum_{i=1}^{I} S_{i}}{I} \quad \text { Vintage }=\frac{\sum_{i=1}^{I} S_{i} * A g e_{i}}{\sum_{i=1}^{I} S_{i}}
$$


In this notation, $i$ indexes firms within a given country industry-pair, $S_{i}$ is a measure of firm size (in this case the number of employees) and $A g e_{i}$ is the age of that firm. In order to see how capital constraints might give rise to distinct effects on size and vintage, it is useful to recast these measures in a setting where there are two cohorts of firms denoted as old $(o)$ and young $(y)$. In such an example, the measures in (1) can be rewritten as:

$$
\text { Average Size }=\frac{N_{o} \bar{S}_{o}+N_{y} \bar{S}_{y}}{N_{o}+N_{y}} \quad \text { Vintage }=\frac{N_{o} \bar{S}_{o} A g e_{o}+N_{y} \bar{S}_{y} \text { Age }_{y}}{N_{o} \bar{S}_{o}+N_{y} \bar{S}_{y}}
$$

where $N$ is the number of old or young firms, $\bar{S}$ is the average size of firms in each cohort and Age is just the respective age of the two cohorts. In this setting, $N_{o} \bar{S}_{o}$ is the employment in the old sector and $N_{y} \bar{S}_{y}$ is employment in the young sector. For the moment, assume that $\bar{S}_{o}>\bar{S}_{y}$.

To see the intuition behind how these measures may diverge, note that if, for example, $N_{o}$ increases and $\bar{S}_{o}$ decreases such that the product, $N_{o} \bar{S}_{o}$, is constant (i.e., they exactly offset each other, so employment in the old sector does not change), then vintage will not have changed while average size will be smaller. More generally, it is useful to consider examples where these two measures move in opposite directions. As an example, consider situations where vintage rises and average size decreases. This can arise for at least two reasons:

i) If $\bar{S}_{o}$ goes down and $N_{o}$ goes up by more than enough to ensure that population shifts to the old sector $\left(\bar{S}_{o}^{\prime}<\bar{S}_{o}, N_{o}^{\prime}>N_{o}\right.$ so that $\left.N_{o}^{\prime} \bar{S}_{o}^{\prime}>N_{o} \bar{S}_{o}\right)$ then vintage will increase and average size will decrease. 
ii) If $\bar{S}_{y}$ goes down and $N_{y}$ does not go up enough so that population in the young sector shrinks $\left(\bar{S}_{y}{ }^{\prime}<\bar{S}_{y}\right.$ and $N_{y}$ is kept at levels so that $\left.N_{y}{ }^{\prime} \bar{S}_{y}{ }^{\prime}<N_{y} \bar{S}_{y}\right)$ then vintage will increase and average size will decrease.

As this example makes clear, average size simply measures the average size of firms and vintage provides a broader measure of where the mass of industrial activity is. Institutional variables need not have similar effects on these two characterizations of activity.

Specifically, if lower capital constraints make it easier to get external financing at earlier stages, the young sector would be smaller on average. At the same time, if firms are able to graduate to being older, larger firms faster (or do not exit or fail as much) the fraction of actual employment in the young sector could be lower. If institutional variables change firm growth patterns in this way, average firm size would be lower and vintage would be higher. The actual effect of capital constraints on these patterns is, consequently, an empirical question.

\subsubsection{Firm Size Distributions and Skewness}

While vintage provides a fuller characterization of the importance of younger firms to economies than firm size, the fullest characterization of industrial activity is likely a firm size distribution and age-specific firm-size distributions. As discussed above, studies of firm-size distributions have tended to be industry specific or country specific. In this paper, we examine the nature of overall and age-specific firm size distributions at the regional, country, and country-industry level. 
Specifically, we examine if the skewness of firm-size distributions is related to the presence of institutional determinants of capital constraints. Additionally, to the degree that skewness of overall firm-size distributions might be associated with other factors, it is useful to consider the relative skewness of the younger firm-size distributions. If capital constraints are operative in shaping the nature of industrial activity, we would expect overall firm-size distribution and, especially the firm size distribution of the younger cohorts, to be skewed.

\subsection{Control Variables}

The level of economic development is likely to affect the attractiveness of becoming an entrepreneur. Greater gross domestic product (GDP) per capita is likely to provide a larger market potential and greater infrastructure for start-ups. In our analysis, GDP per capita is measured by purchasing power parity for residents at the national level. If the level of economic development plays a role in supporting entrepreneurial activity, then we might expect that GDP per capita to have a positive effect on the ability of individuals to successfully become entrepreneurs.

We also include several political and legal variables when available for both Western Europe as well as Central and Eastern Europe. As the previous literature has shown, corruption can play a role in corporate activity. Corruption is defined broadly as "the misuse of public power for private benefits, e.g., bribing of public officials, kickbacks in public procurement, or embezzlement of public funds." Our fairness/corruption index is tabulated by Transparency International and is utilized in Djankov et al. (2000). The index averages the corruption scores given by the following sources: (1) Freedom House Nations 
in Transit; (2) Gallup International; (3) the Economist Intelligence Unit, (4) the Institute for Management Development, Lausanne; (5) the International Crime Victim Survey; (6) the Political and Economic Risk Consultancy, Hong Kong; (7) The Wall Street Journal's Central European Economic Review; (8) the World Bank and the University of Basel; (9) the World Economic Forum. The index is coded on a ten point descending scale from 1 (most corrupt) to 10 (least corrupt).

The second institutional measure that we utilize is protection of property rights. A large economics literature has explored the role that property rights play on the ability to attract capital and ownership structures. From the perspective of an entrepreneur, strong property rights may serve two roles. First, strong property rights might allow older companies to prevent entrepreneurs from starting their own ventures. Alternatively, strong property rights might give young startups an advantage as they compete against established companies. Our measure of protection of property rights is taken from World Economic Forum's “The Global Competitiveness Report 2000," and are defined on a seven point scale, with one denoting nations where property rights are not clearly delineated nor are strongly protected by law and seven indicating cases where property rights are clearly delineated and strongly protected.

We examine the functioning of the legal system in each country through a measure called the Formalism Index. The index, cited in Djankov, et al. (2002), measures substantive and procedural statutory intervention in judicial cases at lower-level civil trial courts, and is formed by adding up the following indices: (1) professionals vs. laymen, (2) written vs. oral elements, (3) legal justification, (4) statutory regulation of evidence, (5) 
control of superior review, (6) engagement formalities, and (7) independent procedural actions. The index ranges from 0 to 7 , where 7 means a higher level of control or intervention in the judicial process.

As discussed above, a number of papers have examined how well the legal system functions. In particular, we look at an index of Interference of Courts that was tabulated by the Survey of World Business Environment from the World Bank Group between 1998 and 2000. This variable captures whether the courts are fair and impartial. The index ranges from 1 to 6 , where 1 means always fair and impartial and 6 never. One might expect that the legal system would be important for protecting new entrants that may be exploited by larger, existing companies. Finally, we include a measure of the procedural burden associated with initiating an enterprise. As developed in Djankov, et al. (2000), the paper employs the number of procedures that a start-up firm must undertake before it can operate legally.

\section{Data and Descriptive Statistics}

The core data used in this paper are the Amadeus data on corporate activity across Europe. Amadeus is a panel dataset of both public and private companies throughout both Eastern and Western Europe. In particular, the dataset covers nearly four million companies in 33 European countries (including all the EU countries) and contains a variety of financial and ownership details.

The original data was provided by Bureau Van Dijk (BvD), a European electronic publishing firm. It specializes in cleaning and organizing data supplied by information 
providers in various countries to create a broader data set. $\mathrm{BvD}$ gathers the national data through information providers of Amadeus data within each country (e.g., Companies House in the UK, Kamers van Koophandel in the Netherlands, INPI in France, National Bank of Belgium). These national companies collect the data from the national public body in charge of collecting the annual accounts in its country. In some countries, particularly those in Central Eastern Europe, the information provider collects the data directly from the companies because of the difficulty obtaining the data from government sources as well as the relative unreliability of the government collected data.

Because of different disclosure requirements, the amount and type of information varies among countries. For instance, some countries have more data on income statement items than on balance sheet items, while firms in other countries have more balance sheet information than income statement information. The completeness of the data also varies: for instance, German regulations are more flexible for small and median enterprises and failure to disclose is not a punishable offence. Appendix A lists the providers of data for the Amadeus Database.

This sample construction method poses a challenge for our analysis. In particular, it is likely that our computations of exit and entry rates, as well as of mean and median firm size, will be affected by the inclusiveness with which the national statistical agency in a particular country collects information. The thoroughness with which these data is collected may vary systematically with other national characteristics that we employ as right-hand side variables in the regressions below. This issue is particularly a concern for 
Western European nations, as the Amadeus data compilers rely exclusively on government databases in those countries.

We address this concern in three ways. First, as discussed above, we employ a variety of dependent variables, rather than simply relying on a single measure. Second, the regression analysis employs industry fixed effects to ensure that within industry variation is emphasized, to counter any selection bias based on varying rules for industry inclusion. Finally, we eliminate all firms with less than twenty employees from the analysis. Because this cut-off point is above that of any reporting nation, it helps insure comparable samples across countries.

This final procedure reduced the sample size substantially, from 3.4 million to just under four hundred thousand firms. We also repeat the analyses below using the entire sample, and find that the results are little changed. The 394 thousand companies include firms from the European Union (Ireland, Great Britain, Italy, Spain, Portugal, Greece, France, Belgium, Germany, Austria, Finland, Sweden, Denmark, Netherlands and Luxembourg) and Central and Eastern European countries (Poland, Czech Republic, Slovakia, Slovenia, Lithuania, Estonia, Latvia, Romania, Bulgaria, Hungary, Croatia, Bosnia H., Yugoslavia, Macedonia, Russia and Ukraine). In addition, Amadeus contains data on companies in Switzerland, Norway, and Iceland.

A number of EU-directives, which aim to harmonize filing requirements, are slowly being implemented. These result in more information being available in the relatively more recent years within the data. Uniformity is achieved by the standardization of accounting information and of industry codifications. BvD has manually allocated a 
CSO code (derived from the UK Statistical Office SIC codes) and an English translation of the trade description for each company allowing activity searching across the database. All national activity codes are cross-referenced to allow cross border searching by a common code. Greater detail on the nature of the Amadeus data and a number of decisions made regarding regional and industrial classifications is provided in Appendix B.

\subsection{Summary Statistics}

Before we start the empirical analysis in the next section, we explore some of the initial summary statistics. In Table 1, we examine summary information by country. Panel A summarizes the data for Western Europe. We tabulate the number of firms in 1998, the number of regions within the country, the number of industries that have companies listed in the national database, the mean and median turnover, mean and median assets, as well as mean and median employees for companies included. The data summary shows the wide variability in the number of companies represented. For example, we only have data on 154 companies in Luxembourg and 152 in Iceland. On the other hand, we have information on 95 thousand companies in Germany and 49 thousand companies in France. These differences reflect both the size of the country, the nature of economic activity, and the criteria for inclusion in the individual national sample.

In addition, regional information varies by countries and seems to be weakly related to the number of companies included in the data. For example, France, Germany, and the UK have the most regions $(26,28$, and 37 respectively) and they also are the three largest countries in terms of reporting companies. In addition, the data within each country generally include information on a large number of industries (between 150 and 215). The 
two exceptions are Iceland and Luxembourg, in which the number of firms reporting in the data is quite low.

In Panel B we present the same summary statistics for countries in Central and Eastern Europe. In most countries, except for Romania, which has 18,000 companies in 1998, the number of companies reporting is somewhat smaller than we saw in Panel A for Western Europe. When we look at the number of regions in the country, we find that the average number of regions per country is quite a bit smaller than Western Europe.

Data on turnover, assets, and employees demonstrates that the data is highly skewed. Mean values of turnover, assets, and employees are typically substantially larger than the median values. This is not surprising given that we expect a skewed distribution of firm size.

Mean turnover is lowest in Macedonia with a mean turnover of just under $\$ 500,000$ and a median turnover of $\$ 119,000$. The largest mean turnover is Switzerland with a mean of \$321 million and a median of \$51 million. Assets show a similar skewness. The lowest average asset levels are again in Macedonia, with the largest average assets are in Switzerland. Finally, dispersion on the number of employees is quite large. Average sizes are relatively small in all countries. The largest average number of employees is 727 in Luxembourg, a country where only 154 companies reported. In Estonia ,the other extreme, the average company had 81 employees. Median numbers of employees are substantially lower for all firms. 
Table 2 presents the same summary statistics, but now by industry, not country. For example, the first industry listed is coal mining. The Amadeus data has information on coal mining companies in 26 countries. These firms are, generally, quite large, 2,460 people, although the median is substantially lower, 403. This likely is a result of a small number of very large mining companies and a large number of small firms. The largest numbers of companies fall into the wholesale trade category (44,000 firms) with firms listed in every country. These firms tend to be quite small, having an average of 194 employees and a median of 44 employees.

\section{Analysis}

In order to understand the nature of entrepreneurial activity across economies, the analysis that follows considers the determinants of entry, exit, average firm size, industrial vintage, and the skewness of the firm-size distributions throughout Europe and, subsequently, in Western and Eastern Europe separately. While entry and exit rates capture activity in a given year, the other measures reflect longer-run determinants of industrial activity.

\subsection{The Determinants of Entry and Exit}

Studies of entrepreneurial activity have often examined entry and exit rates. Within an economy, higher entry rates have typically been viewed as an indicator of dynamic economies. Our goal is to understand how legal, institutional, and regulatory factors affect entry and exit. Our measures of entry and exit examine that activity within a particular 
industry for a particular country. We thus use countries crossed with industries as our unit of observation.

In Table 3, the dependent variable is the rate of entry within each country-industry cell for 1998, calculated as the ratio of new firms in 1998 to all firms in 1997 . In all specifications presented in Table 3, industry fixed effects are included to control for the distinctive nature of industries. Similarly, GDP per capita is employed in all specifications to control for the overall level of economic development.

Independent variables measure the quality of legal and political institutions. In particular, coefficients are reported for an index of fairness (the inverse of corruption), a measure of the strength of property right protection, a formalism index, an index of the interference of courts, and a measure of start-up procedures. Because some of these measures are highly correlated with each other, we use only one of these variables in each regression. Thus, each column presents the results of five separate regressions.

In this first specification of Panel A, negative but statistically insignificant coefficients are associated with the fairness index and the property rights index. The measures associated with the judiciary are more mixed. In nations characterized by higher levels of formalism, there is no significant effect, but those characterized by greater degrees of interference by the judiciary have significantly lower entry.

Column 2 incorporates a dummy variable for Central and Eastern Europe (CEE). This measure is consistently negative and significant, suggesting that this region is characterized by lower rates of entry. Inclusion of the CEE dummy has little effect on the 
level and significance of the coefficients on the other independent variables, but suggests the need to separately consider Western Europe and the CEE. In particular, given the recent transitions of many CEE economies, the effects of political, legal, and regulatory variables may be more pronounced.

Columns 3 and 4 of Table 3 employ the same empirical framework employed in Column 1, but separately estimate entry regressions for Western Europe and the CEE. Several results emerge from this separation:

- The dominant pattern is that political, legal, and regulatory institutional structures matter far more in Central and Eastern Europe than in Western Europe. All five variables are statistically significant in the CEE regressions; while only one (the measure of court interference) is in the Western Europe regressions. This pattern reflects the relative importance of the differing institutional environments. In the CEE, differences in institutional environment are clearly first order while in Western Europe these considerations seem second order.

- Greater fairness and stronger property rights are unambiguously associated with higher rates of entry in Central and Eastern Europe. Similarly, greater judicial interference and formalism are associated with lower entry. Somewhat puzzlingly, in nations where more start-up procedures are required, there is more entry as well. This reflects the fact the measure of start-up procedures is highly correlated with the fairness index. Not surprisingly, when both measures are used in a multivariate regression, the measure of start-up procedures is usually significantly negative. 
- The only measure significant in Western Europe is that more interference in the courts is associated with greater entry.

Taken together, the results indicate that the dynamics of entry are distinctive in Western Europe and CEE, with institutional considerations having a far more profound effect on entry in Central and Eastern Europe.

Panel B repeats the analysis. Instead of estimating ordinary least squares regressions, we now employ median regressions, which should be less sensitive to outliers. The results are similar to those from before. Greater fairness and protection of property rights are only associated with more entry in Central and Eastern Europe. The two judicial measures are now consistently significant and negative in the CEE, while they are significant and positive in the Western Europe. More start-up procedures are now associated with more entry throughout Europe.

The dynamics that affect entry are also likely to have an impact on the rate of exit for a given industry with a country. Table 4 takes a similar empirical approach to that in Table 3 to examine exit in Europe. Columns 1 and 2 suggest that greater fairness and stronger property rights are associated with lower rates of entry, but the significant coefficient on the CEE dummy suggests the importance of considering Western Europe and CEE separately. Segregation of the two sub-regions in columns 3 and 4 demonstrates that, much like in the case of entry, different dynamics of exit exist in Western Europe and the CEE. Specifically, fairer countries are associated with lower rates of exit throughout Europe, but the effect is about thirteen times larger in the CEE. Nations with stronger property rights have significantly lower exit rates, but only in Eastern Europe. Finally, 
greater legal formalism and more interference by courts are associated with lower exit rates in Western Europe while no pattern is seen in the CEE. Results are similar in the median regressions in Panel B.

These patterns are consistent with those seen in the analysis of entry above. The institutional environment appears to matter more in Central and Eastern Europe. A consistent pattern appears in these nations, with stronger property rights and greater fairness being associated with a more favorable environment for entrepreneurs (more entry and less exit). The results of our political, legal, and regulatory variables in Western Europe are far less consistent and are more difficult to understand. It appears that there is no consistent effect of these institutional variables on entry and exit. It may be the case that other factors - distinctive levels of human capital investment, for example - matter much more in more mature economies.

\subsection{The Determinants of Average Firm Size}

Average firm size offers another perspective on the dynamics of firm growth by not emphasizing entry and exit in one year, but by considering a snapshot of overall industrial activity. As noted above, greater fairness and stronger property rights are associated in the CEE countries with greater entry and lower exit. This pattern may lead to either larger or smaller average firm size.

Table 5 considers the determinants of average firm size, employing the same empirical framework as we did for entry and exit. Once again, the dependent variable is the average firm size for firms within a given industry in a particular country. As with 
Tables 3 and 4, columns 1 and 2 of Table 5 consider the pooled European sample with and without a CEE dummy. In both specifications, fairer countries and those with stronger property rights are associated with smaller firms. Lower levels of legal formalism, greater levels of interference by the courts, and more start-up procedures are associated with larger average firm size.

These results, however, differ when we consider Western Europe and CEE separately. Specifically, higher levels of fairness and stronger property rights are associated with smaller average firm size in CEE. This result is consistent with the analysis above: the institutional environment appears to matter critically in creating a favorable atmosphere for entrepreneurship in Central and Eastern Europe.

The results in Western Europe are far smaller in magnitude. Moreover, they suggest that nations with greater fairness are associated with larger, not smaller, firms. As before, the results for the legal variables are different in sign: lower levels of legal formalism and greater levels of interference by the courts are associated with larger firm size in both sets of nations. The results on columns 7 and $8-$ when we estimate median regressions - are quite similar. Once again, we find that the institutional factors matter more for entrepreneurial activity in CEE, but have much weaker effects in Western Europe.

\subsection{The Determinants of Industrial Vintage}

As discussed in Section 3, the measure of industrial vintage offers a summary measure of industrial activity that integrates average firm size with measures of age. 
Industrial vintage captures the relative contribution of entrepreneurial firms to overall industry output. This measure may be closely correlated with average firm age, or may be quite distinct, if institutional variables affect firm growth patterns differently in various nations.

As above, the analysis of industrial vintage presented in Table 6 considers the effects of fairness, property rights protection, legal variables and startup procedures on the relative importance of young firms to industrial activity. The analysis presented here employs a measure of vintage based on employees, given the greater consistently with which this measure is reported. Unreported analyses using vintage measures based on turnover and assets are, however, not significantly different, as are those using different weighting schemes. We once again use industry-country pairs as our unit of analysis.

The first two columns of Table 6 consider the overall pooled European sample with and without the presence of a CEE dummy. Greater fairness is associated with a higher vintage, while results for protection of property rights is inconsistent. More interference in the courts and less formalism are also associated with a higher vintage. When we look at the sets of nations separately, greater fairness and stronger property rights are associated with higher vintage in both of the two regions. In Western Europe, greater formalism is associated with lower vintage. In CEE nations, greater inference with the courts is associated with higher vintage. The results are similar when we estimate median regressions.

What do the distinctive results on vintage and average size indicate? As noted before, in CEE nations, greater fairness is associated with more entry and less exit. When 
we look at average firm size, fairness is associated with smaller firms, but the opposite effect holds when we look at vintage. This suggests that while fairer nations, particularly in Central and Eastern Europe, are not only associated with higher rates of entry, but that fairer countries allow the surviving firms to grow large. In general, the distinction between the results on vintage suggest two things: the inadequacy of any one measure at capturing the nature of entrepreneurial activity and the importance of institutional factors in influencing both the birth of firms and their transition into older, larger firms.

\subsection{Skewness of the Firm Size Distribution}

Finally, we turn to the effect of the institutional environment on the distribution of firm sizes. As noted in Section 2, Cooley and Quadrini (2002) and Cabral and Mata (2003) argue that in the presence of capital constraints, the firm size distribution will be skewed. In this section, we examine the distribution of firm size across various industries, following the same approach as above.

Figures 1 through 3 provide a graphical preview of the results. Figure 1 shows the distribution of firm size in Western Europe, with the number of firms plotted against the logarithm of sales. The overall distribution is skewed, with a skewness of 0.87 . When we break down the distribution by firm age, we find that the distribution of firms under 10 years of age are the most highly skewed and that skewness decreases with age. Figure 2 provides a similar representation for Central and Eastern Europe. The comparison between the regions is instructive. First, the overall distribution is more highly skewed, with a skewness of 1.18. Moreover, when we break down the distribution by firm age, we find that firms under 10 years of age are even more highly skewed and that firms that are more 
than ten years old have size distributions that are very close to a lognormal distribution. In Figure 3, we provide a similar analysis for one country - Great Britain, a country in Western Europe with a highly developed capital market. Not only is the overall distribution much less skewed (0.37), but the differences in skewness by cohort are much less pronounced.

These figures motivate the analyses reported in Tables 7 and 8 . The dependent variable in the first table is the skewness of the firm size distribution in each industry in every sample country. In the latter one, we employ the difference between the skewness of the distribution of firms below the median age and those above this threshold. Once again, each industry-country pair is employed as a distinct observation.

When we examine the level of skewness in Table 7 , we find that nations with greater fairness and stronger property rights are associated with less skewness. Similarly, firms with a higher level of formalism are associated with more skewness. The results regarding fairness and property rights, however, stem exclusively from the CEE nations in the sample. No significant effects are seen in the Western Europe. In both sets of nations, more formalism is associated with greater skewness. More judicial interference is associated with less skewness, but only in Western Europe. The results are very similar when we estimate median regressions in Panel B.

Table 8 examines the difference in the skewness of the size distribution in particular industries for firms that are below the median age compared to firms that are above the median age. Greater fairness reduces the difference between the skewness of the size distribution for younger firms compared to the skewness of the size distribution for 
older firms. The results are consistent with the capital constraints explanation. In nations where institutions are less fair and property rights weak, the presence of capital constraints may lead to a particularly skewed distribution for younger firms, who are less likely to be able to finance all positive net present value investment opportunities from internally generated cash flows.

\section{Conclusion}

This paper seeks to demonstrate the effects of institutional constraints on the real activities of firms, with a focus on entrepreneurship. These firms are of interest for two reasons. First, entrepreneurial firms in many respects represent testing grounds for scholars interested in how frictions can affects the workings of companies and markets. Second, encouraging entrepreneurship is of intense interest to policymakers. Understanding the critical links between institutional development and entrepreneurial activity is critical, especially in emerging and transitioning economies.

Our focus on political, legal, and regulatory factors is motivated by work that has demonstrated their importance to the development of capital markets. The results suggest a strong influence of the institutional environment in shaping firm dynamics. The results regarding entry, exit, firm size, vintage, and skewness tell a consistent story. Greater fairness and stronger protection of property rights are critically important in encouraging both the emergence and growth of new enterprises, particularly in emerging markets. The results are much less clear-cut in Western Europe. To us, this suggests that in more developed economies, these institutional effects may be second order to the many other unobserved factors that may affect entrepreneurial dynamics. Examples of such 
considerations that have been highlighted in earlier studies include tax codes (Gentry and Hubbard (2002) and Cullen and Gordon (2003)), labor market conditions (Gromb and Scharfstein (2001)), and the supply of new ideas.

Our results suggest several avenues for further research. First, while studies of entrepreneurship typically emphasize entry, our results suggest that there may exist another critical point in firm maturation where institutions impact the ability of firms to graduate into larger firms. As a consequence, entry rates alone are an inadequate measure of entrepreneurial dynamism. The identification of the determinants of how institutions impact this maturation process must be better understood. Second, the inability of our institutional variables to explain many of the patterns seen in Western Europe raises the question of what factors influence entrepreneurial activity in more developed markets. Finally, establishing the links between these measures of entrepreneurship and broader economic growth remains a central open question in this literature.

It is our hope to continue to explore these important issues in a European setting. The high degree of disclosure of information on privately held firms in Europe, in combination with the broad scope of the Amadeus dataset, will hopefully provide greater insight into these questions of entrepreneurial dynamics. 


\section{References}

Cabral, Luis and Jose Mata, 2001, "On the Evolution of the Firm Size Distribution: Facts and Theory," Unpublished working paper, New York University, October 2001.

Cooley, Thomas F., and Vincenzo Quadrini, 2003, "Common Currencies vs. Monetary Independence," Review of Economic Studies, 70, 785-806.

Cullen, Julie Berry and Roger H. Gordon, 2002, "Taxes and Entrepreneurial Activity: Theory and Evidence for the U.S.," Working Paper No. 9015, National Bureau of Economic Research.

Davis, Steven J., and Magnus Henrekson, 1999, "Explaining National Differences in the Size and Industry Distribution of Employment," Small Business Economics, 12, 59-83.

Davis, Steven J., John C. Haltiwanger, and Scott Schuh, 1996, Job Creation and Destruction, Cambridge, MIT Press.

Demirguc-Kunt, Asli, and Vojislav Maksimovic, 1998, "Law, Finance, and Firm Growth," Journal of Finance, 53, 2107-2137.

Devereux, M. and F. Schiantarelli, 1990, "Investment, Financial Factors and Cash Flow: Evidence from UK Panel Data" in R. Glenn Hubbard (editor), Asymmetric Information, Corporate Finance and Investment, Chicago, University of Chicago Press.

Djankov, Simeon, Rafael La Porta, Florencio Lopez-de-Silanes, and Andrei Shleifer, 2000, "The Regulation of Entry," Working Paper No. 7892, National Bureau of Economic Research.

Djankov, Simeon, Rafael La Porta, Florencio Lopez-de-Silanes, and Andrei Shleifer, 2002, "Courts: The Lex Mundi Project," Working Paper No. 8890, National Bureau of Economic Research.

Dunne, Timothy, Mark J. Roberts, and Larry Samuelson, 1988, "Patterns of Firm Entry and Exit in U.S. Manufacturing Industries," Rand Journal of Economics, 19, 495-515.

Dunne, Timothy, Mark J. Roberts, and Larry Samuelson, 1989, “The Growth and Failure of U.S. Manufacturing Plants," Quarterly Journal of Economics, 104, 671-698.

Ericson, Richard, and Ariel Pakes, 1995, "Markov-Perfect Industry Dynamics: A Framework for Empirical Work," Review of Economic Studies, 62, 53-82.

Evans, David S., 1987, "Tests of Alternative Theories of Firm Growth," Journal of Political Economy, 95, 657-674.

Evans, David S., and Linda S. Leighton, 1989, "Some Empirical Aspects of Entrepreneurship," American Economic Review, 79, 519-535. 
Fazzari, Steven M., and Bruce C. Petersen, 1993, "Working Capital and Fixed Investment: New Evidence on Finance Constraints,', RAND Journal of Economics, 34, 328-342.

Fazzari, Steven M., R. Glenn Hubbard, and Bruce C. Petersen, 1988, "Financing Constraints and Corporate Investment,' Brookings Papers on Economic Activity, 141195.

Frye, Timothy and Andrei Shleifer, 1997, "The Invisible Hand and the Grabbing Hand" American Economic Review Papers and Proceedings, 87, 354-358

Gentry, William M. and Glenn Hubbard, 2002, "Entrepreneurship and Household Saving," Unpublished working paper, Columbia University.

Graham, John R., and Campbell R. Harvey, 2001, “The Theory and Practice of Corporate Finance: Evidence from the Field", Journal of Financial Economics, 60, 187-243

Gromb, Denis, and David Scharfstein, 2001, "A Model of Entrepreneurial Activity," Unpublished working paper, Massachusetts Institute of Technology.

Hall, Bronwyn H., 1987, "The Relationship between Firm Size and Firm Growth in the U.S. Manufacturing Sector,” Journal of Industrial Economics, 35, 583-606.

Himmelberg, Charles P., and Bruce C. Petersen, 1994, "R\&D and Internal Finance: A Panel Study of Small Firms in High-Tech Industries,' Review of Economics and Statistics, $56,38-51$.

Holtz-Eakin, Douglas, David Joulfaian, and Harvey S. Rosen, 1994a, "Sticking It Out: Entrepreneurial Survival and Liquidity Constraints," Journal of Political Economy, 102, 53-75.

Holtz-Eakin, Douglas, David Joulfaian, and Harvey S. Rosen, 1994b, "Entrepreneurial Decisions and Liquidity Constraints," Rand Journal of Economics, 25, 334-347

Hoshi, Takeo, Anil Kayshap, and Jeremy Scharfstein, 1991, "Corporate Structure, Liquidity and Investment: Evidence from Japanese Industrial Groups," Quarterly Journal of Economics, 106, 33-60.

Johnson, Simon, and Gary Loveman, 1995, Starting Over in Eastern Europe: Entrepreneurship and Economic Renewal, Boston, Harvard Business School Press

Johnson, Simon, John McMillan, and Christopher Woodruff, 2002, "Property Rights and Finance," American Economic Review, 92, 1335-1356.

Jovanovic, Boyan, 1982, "Selection and the Evolution of Industry," Econometrica, 50, 649-670.

Jovanovic, Boyan, and Glenn M. MacDonald, 1994, "The Life Cycle of a Competitive Industry," Journal of Political Economy, 102, 322-347.

King, Robert G., and Ross Levine, 1993, "Finance and Growth: Schumpeter Might Be Right," Quarterly Journal of Economics, 108, 713-737.

Klepper, Steven, and Elizabeth Graddy, 1990, “The Evolution of New Industries and the Determinants of Market Structure," Rand Journal of Economics, 21, 27-44. 
Klepper, Steven, and Kenneth L. Simons, 2000, "The Making of an Oligopoly: Firm Survival and Technological Change in the Evolution of the U.S. Tire Industry," Journal of Political Economy, 108, 728-760.

Knack, Stephen and Philip Keefer, 1995, "Institutions and Economic Performance: Cross Country Tests Using Alternative Institutional Measures," Economics and Politics, 7 (November), 207-228

Kumar, Krishna B., Raghuram G. Rajan, and Luigi Zingales, 1999, "What Determines Firm Size?," Working Paper No. 7208, National Bureau of Economic Research.

La Porta, Rafael, Florencio Lopez-de-Silanes, Andrei Shleifer, and Robert Vishny, 1998, "Law and Finance," Journal of Political Economy, 106, 1113-1155,

La Porta, Rafael, Florencio Lopez-de-Silanes, and Andrei Shleifer, 1999, "Corporate Ownership Around the World," Journal of Finance, 54, 471-517.

La Porta, Rafael, Florencio Lopez-de-Silanes, Andrei Shleifer, and Robert Vishny, 2000, "Investor Protection and Corporate Governance," Journal of Financial Economics, 58, 125

Lamont, Owen, 1997, "Cash Flow and Investment: Evidence from Internal Capital Markets," Journal of Finance, 52, 83-109.

Lucas, Robert E, Jr., 1978, “On the Size Distribution of Business Firms," Bell Journal of Economics, 9, 508-523.

Mansfield, Edwin, 1962, "Entry, Gibrat's Law, Innovation, and the Growth of Firms," American Economic Review, 52, 1023-1051.

Myers, Stewart C., 1977, "Determinants of Corporate Borrowing." Journal of Financial Economics, 5, 147 - 175

Myers, Stewart C., and N. Majluf, 1984, "Corporate Investment and Financing Decisions When Firms Have Information That Investors Do Not Have," Journal of Financial Economics, 13, 187-222.

Rajan, Raghuram G. and Luigi Zingales, 1998, "Financial Dependence and Growth," American Economic Review, 88, 559-586.

Shin, Hyun-Han, and Rene Stulz, 1998, "Are Internal Capital Markets Efficient?," Quarterly Journal of Economics, 113, 531-552.

Shleifer, Andrei, 1997, "Government in Transition," European Economic Review, 41, 385410.

Simon, Herbert, and C. Bonnini, 1958, "The Size Distribution of Business Firms," American Economic Review, 48, 607-617.

Stiglitz, Joseph E., and Andrew Weiss, 1981, "Credit rationing in Markets with Imperfect Information," American Economic Review, 71, 393-410.

Sutton, John, 1997, “Gibrat's Legacy,” Journal of Economic Literature, 35, 20-49

Townsend, R., 1979, "Optimal Contracts and Competitive Markets with Costly State Verification," Journal of Economic Theory, 21, 1-29. 
Appendix A: Information Providers by Country

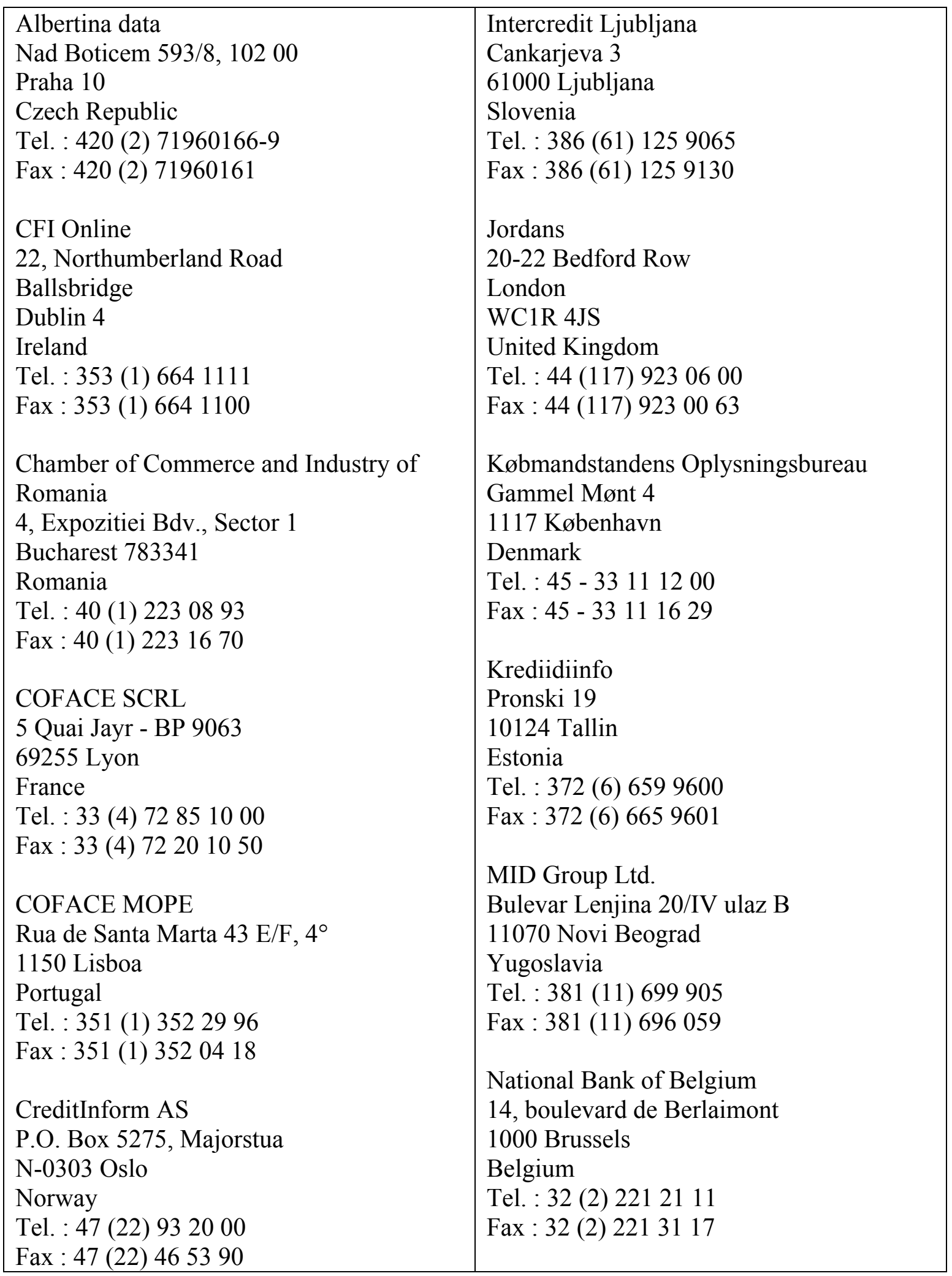




\begin{tabular}{|c|c|}
\hline $\begin{array}{l}\text { Creditreform Croatia } \\
\text { ul. Baruna Trenka } 13 \\
\text { 10000 Zagreb } \\
\text { Croatia } \\
\text { Tel. : } 385 \text { (1) } 4577768 \\
\text { Fax : } 385 \text { (1) } 4573112 \\
\text { Intercredit Budapest } \\
\text { Kálvária tér } \\
\text { 71089 Budapest } \\
\text { Hungary } \\
\text { Tel. : } 36 \text { (1) } 3039300 \\
\text { Fax : } 36 \text { (1) } 2102728\end{array}$ & $\begin{array}{l}\text { Novcredit } \\
\text { Via dell'Artigianato } \\
20090 \text { Vimodrone (Milano) } \\
\text { Italy } \\
\text { Tel. : } 39 \text { (2) } 250100.1 \\
\text { Fax : } 39 \text { (2) } 25007070 \\
\text { Patikimo Verslo Sistema } \\
\text { P.O. Box 2878 } \\
\text { 2000 Vilnius } \\
\text { Lithuania } \\
\text { Tel. : } 370 \text { (2) } 224133 \\
\text { Fax : } 370 \text { (2) } 224133 \\
\text { UC } \\
\text { 11496 Stockholm } \\
\text { Sweden } \\
\text { Tel. : } 46 \text { (8) } 6709000 \\
\text { Fax : } 46 \text { (8) } 6614832 \\
\text { Verband der Vereine Creditrefom } \\
\text { Hellersbergstraße } 12 \\
41415 \text { Neuss } \\
\text { Germany } \\
\text { Tel. : } 49 \text { (2131) } 10910 \\
\text { Fax : } 49 \text { (2131) } 1098000\end{array}$ \\
\hline
\end{tabular}




\section{Appendix B: Characteristics of the Sample}

\section{B.1 Company-Level Data}

The Amadeus data contains over 130 variables of information for the companies within the data set. Company profile variables include the geographical location, identification number, legal form, etc. In addition, industry codes are included. Because of differences across countries, there are more than 15 different industry codes and its corresponding descriptions (see next section for greater details on industry codes). The data also provides information on the firms' managers and auditors. Typically, the data would include information on up to 10 managers. In addition, standard balance sheet and income statement items are tracked. The exact financial information captured differs depending upon the data collected within the country.

One of the interesting aspects of the data is information on ownership and subsidiaries. These data include owners' and subsidiary's identification number, country, turnover, date of acquisition, and percentage of ownership (up to 10 owners and subsidiaries per company). Ultimate holding company data is also available for some companies. Depending upon the country, these data is available for both public and private companies.

\section{B.2. Types of Companies}

The inclusion criteria used by Bureau van Dijk Amadeus differs by country, relying on individual national filing requirements for the core data. State-owned companies as well as privately owned firms are included. Banks and insurance companies are not included. Two different types of companies are included in the Amadeus data. Type 1 companies are those whose capital is divided into shares which can be offered to the general public and whose members are only liable for its debts to the extent of any amount unpaid on their shares. Type 2 companies are those whose capital is divided into shares that cannot be offered to the general public. The liability of its members is limited to the amount of their shares. Finally, the database includes information on other entities including partnerships (IHG, KG, K/S, Ky, Kb, SNC, SC, G,bH \&Co, KG, SapA, Sas, Snc, ANS, K/s, HB, KB) and sole proprietorships (SURL, EVBA, Sole proprietorships, OE, EE), and cooperatives. Table A-1 illustrates a breakdown of Type 1 and Type 2 companies by country.

\section{B.3. Industry Classifications}

Our analysis exploits industry level information in the data across countries. As such, we need to have common industry definitions within the data. All firms in the Amadeus data have an identifier used by the national body collecting the data. Typically, these codes are unique to the individual country. In addition to the national industry codes assigned by the information provider in each country, detailed uniform 7-digit CSO activity codes are assigned by Bureau van Dijk to all of the companies in the database. The CSO activity codes have been assigned to each company from the standard list of 8,000 activities produced by the British Central Statistical Office (CSO). All the codes (NAF, ATECO, WZ, SIC-UK, BIK, ISIC, SIC-US, etc.) are cross-referenced to the CSO activity code. In addition, NACE codes (Statistical Classification of Economic Activities in the 
European Community) are the basis for many of the new updated and more harmonized national codes. All countries in the EU are now obligated to create new classifications whose first three digits are based on NACE 1.

Bureau Van Dijk has provided a spreadsheet with conversion codes between the various industry classifications. Also, Amadeus online allows users to obtain all the corresponding codes to a particular code.

\section{B.4. Ownership and Subsidiary Data}

Bureau Van Dijk merges ownership data that it receives from all its information providers into one large database. This information is then analyzed to identify each cross border holding/subsidiary link by the national identification number of the companies involved.

This means that all subsidiaries that European companies have in countries outside Europe that are not reported to the national statistical office do not appear in the subsidiary section of the company. Those subsidiaries overseas disclose information to their national office. Thus, if a French company has one subsidiary in Spain and two in Canada, the Spanish Information provider will report data on its French parent company that will be then linked to the French company as a subsidiary. Because Amadeus has no information provider from Canada, there is no way to find out if the French company has a Canadian subsidiary unless the company reports it.

Ownership and subsidiary data are dated corresponding with the latest statement available for the parent company. Ownership and subsidiary data usually include the name and identification number of both the parent and the subsidiary, which can be then tracked within the database, percentage of ownership (direct and total), turnover, and date of acquisition. If a company has more than 10 owners or subsidiaries, only the largest 10 will be reported. There is also information on ultimate shareholder, including identification number, country, type, and turnover.

\section{B.5. Regional Information}

The data by country is further divided into regions. The regions within the Amadeus dataset are based upon the definitions of regions defined in the European Commission's Eurostat. Eurostat's regional statistics cover the principal aspects of the economic and social life, such as demography, economic accounts, employment, unemployment, and so forth. Eurostat attempts to group together population or places with sufficient similarities to comprise a logical unit for administrative purposes. Eurostat, in collaboration with the other Commission departments, set up the Nomenclature of Statistical Territorial Units (NUTS) at the beginning of the 1970s as a single, coherent system for dividing up the European Union's territory.

As of yet, the NUTS classification has no specific legal basis, i.e. there is no regulation that sets rules for compiling and updating the system of regional reporting and boundaries. These matters have been settled so far by "gentlemen's agreements" between the Member States and Eurostat, sometimes after long and difficult negotiations. The NUTS scheme is then published by Eurostat (the latest edition came out in 1999). NUTS is a hierarchical classification scheme, with three levels of aggregation referred to as NUTS Levels 1, 2, and 3 (the finest partition). 
Figure 1: Firm Size Distributions for Western Europe, Overall and by Cohort, 1998

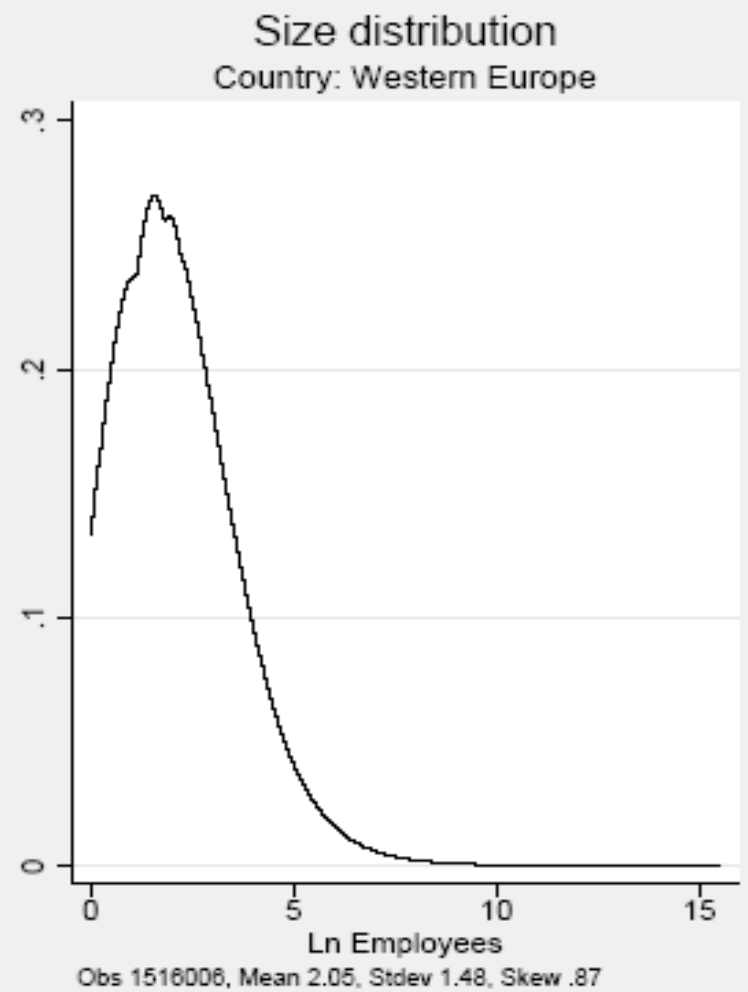

Size distribution by age
Country: Western Europe
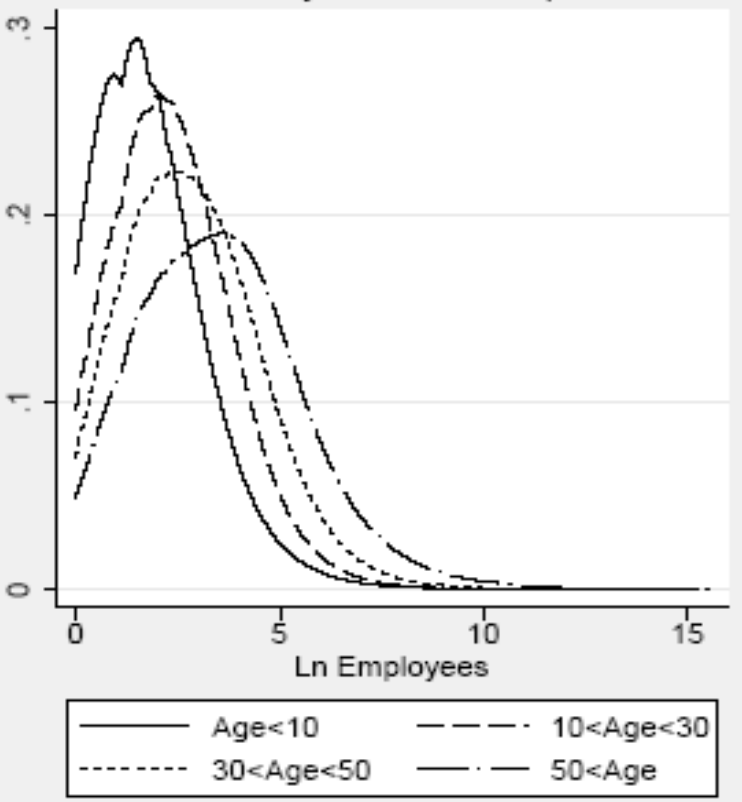

$(<10)$ Obs 816504 , Mean 1.73, Stdev 1.34, Skew .97

$(10-30)$ Obs 510799 , Mean 2.31. Stdev 1.45, Skew .61 $(30-50)$ Obs 91670 , Mean 2.79 . Stdev 1.66 , Skew .55

Note: The left panel depicts the overall firm size distribution for Western Europe in 1998. The right panel depicts the size distribution by cohort. Summary statistics for the distributions are provided at the bottom of the panels.

Figure 2: Firm Size Distributions for Central and Eastern Europe, Overall and by Cohort, 1998
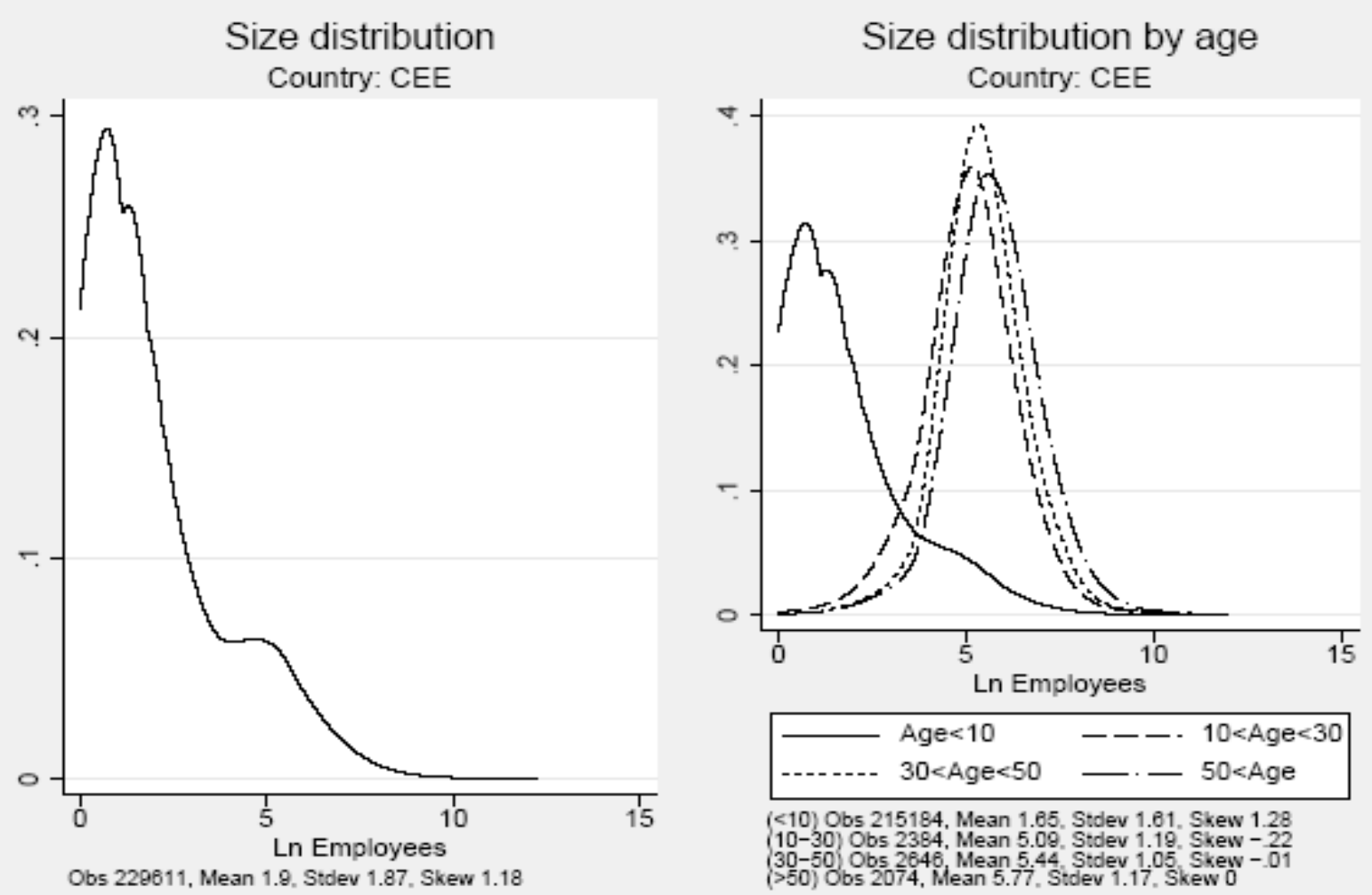
Figure 3: Firm Size Distributions for the United Kingdom, Overall and by Cohort, 1998
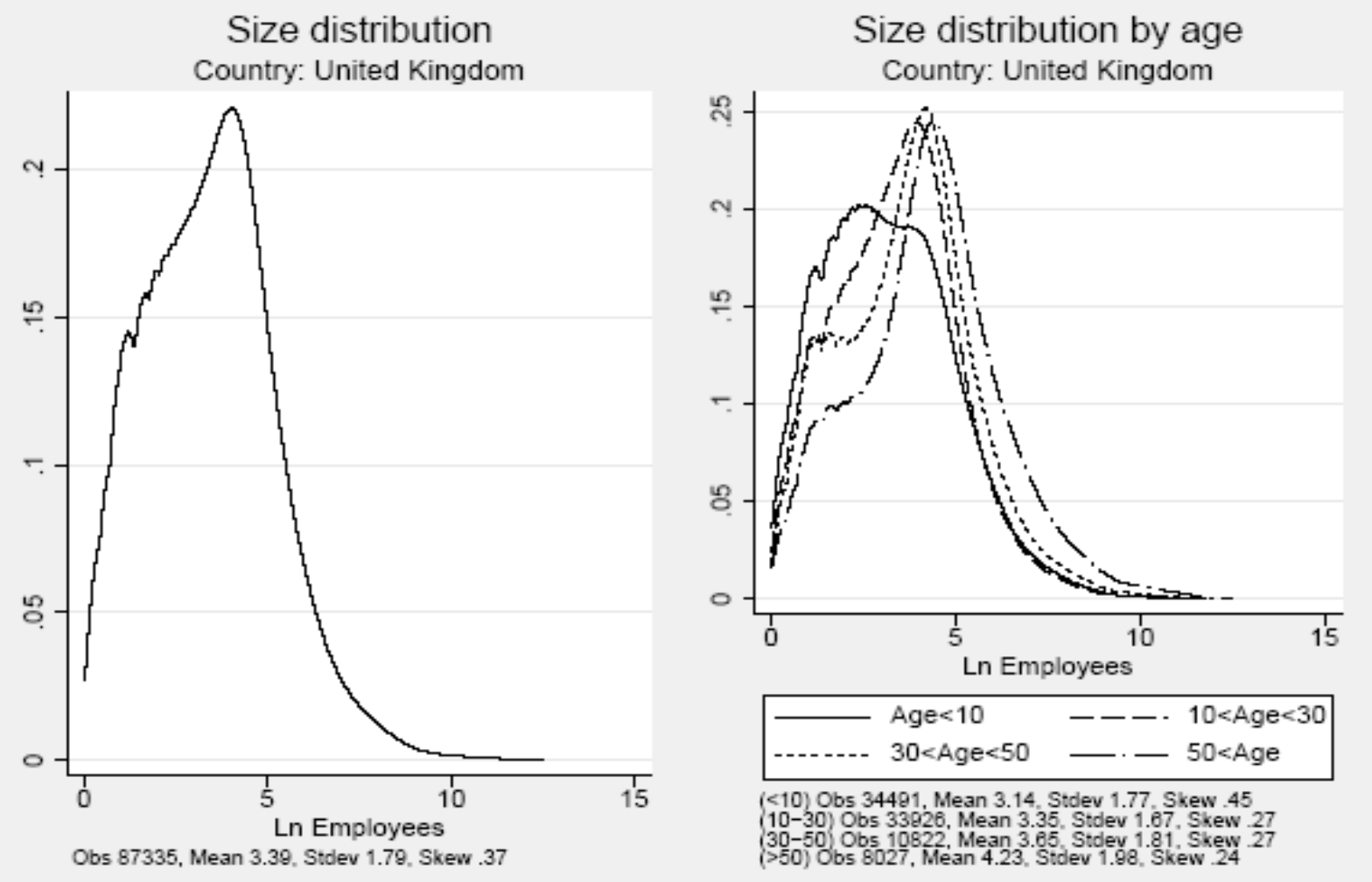

Note: The left panel depicts the overall firm size distribution for the United Kingdom in 1998. The right panel depicts the size distribution by cohort. Summary statistics for the distributions are provided at the bottom of the panels. 
Table 1

Descriptive Statistics by Country, 1998

\begin{tabular}{|c|c|c|c|c|c|c|c|c|c|}
\hline Country & $\begin{array}{l}\text { Number of } \\
\text { Firms }\end{array}$ & $\begin{array}{l}\text { Number of } \\
\text { Regions }\end{array}$ & $\begin{array}{l}\text { Number of } \\
\text { Industries }\end{array}$ & $\begin{array}{l}\text { Mean Revenues } \\
\text { (\$ thousands) }\end{array}$ & $\begin{array}{c}\text { Median } \\
\text { Revenues } \\
\text { (\$ thousands) }\end{array}$ & $\begin{array}{l}\text { Mean Assets } \\
\text { (\$ thousands) }\end{array}$ & $\begin{array}{l}\text { Median Assets } \\
\text { (\$ thousands) }\end{array}$ & $\begin{array}{c}\text { Mean } \\
\text { Employment }\end{array}$ & $\begin{array}{c}\text { Median } \\
\text { Employment }\end{array}$ \\
\hline \multicolumn{10}{|l|}{ Panel A: Eurozone } \\
\hline Austria & 7,380 & 9 & 53 & $\$ 25,442$ & $\$ 5,655$ & $\$ 159,313$ & $\$ 31,384$ & 129 & 45 \\
\hline Belgium & 11,273 & 11 & 55 & $\$ 51,272$ & $\$ 10,384$ & $\$ 43,422$ & $\$ 4,461$ & 127 & 39 \\
\hline Denmark & 8,304 & 1 & 53 & $\$ 65,271$ & $\$ 18,047$ & $\$ 26,905$ & $\$ 4,411$ & 174 & 43 \\
\hline Finland & 4,613 & 6 & 52 & $\$ 61,280$ & $\$ 7,062$ & $\$ 53,479$ & $\$ 3,937$ & 264 & 48 \\
\hline France & 49,434 & 27 & 55 & $\$ 46,304$ & $\$ 6,524$ & $\$ 43,161$ & $\$ 3,285$ & 231 & 42 \\
\hline Germany & 95,315 & 44 & 56 & $\$ 62,490$ & $\$ 6,251$ & $\$ 712,887$ & $\$ 109,763$ & 264 & 45 \\
\hline Greece & 5,438 & 13 & 53 & $\$ 14,193$ & $\$ 3,577$ & $\$ 16,761$ & $\$ 3,524$ & 109 & 42 \\
\hline Iceland & 152 & 1 & 30 & $\$ 47,689$ & $\$ 21,916$ & $\$ 52,962$ & $\$ 17,369$ & 216 & 125 \\
\hline Ireland & 913 & 2 & 47 & $\$ 124,787$ & $\$ 27,979$ & $\$ 82,630$ & $\$ 10,632$ & 381 & 87 \\
\hline Italy & 38,556 & 20 & 55 & $\$ 35,619$ & $\$ 7,424$ & $\$ 39,459$ & $\$ 6,135$ & 287 & 41 \\
\hline Luxembourg & 154 & 1 & 31 & $\$ 250,100$ & $\$ 34,643$ & $\$ 365,893$ & $\$ 20,420$ & 775 & 154 \\
\hline Netherlands & 10,760 & 12 & 55 & $\$ 129,378$ & $\$ 7,019$ & $\$ 90,544$ & $\$ 8,764$ & 467 & 81 \\
\hline Norway & 6,842 & 1 & 54 & $\$ 30,008$ & $\$ 5,765$ & $\$ 27,356$ & $\$ 2,738$ & 97 & 38 \\
\hline Portugal & 2,751 & 7 & 52 & $\$ 30,601$ & $\$ 4,649$ & $\$ 39,677$ & $\$ 3,458$ & 221 & 53 \\
\hline Spain & 30,882 & 17 & 55 & $\$ 23,447$ & $\$ 4,145$ & $\$ 22,175$ & $\$ 2,829$ & 526 & 39 \\
\hline Sweden & 13,604 & 8 & 54 & $\$ 50,904$ & $\$ 7,644$ & $\$ 57,971$ & $\$ 3,873$ & 605 & 42 \\
\hline Switzerland & 6,703 & 1 & 52 & $\$ 321,396$ & $\$ 50,592$ & $\$ 906,497$ & $\$ 128,137$ & 473 & 50 \\
\hline United Kingdom & 50,099 & 37 & 56 & $\$ 87,030$ & $\$ 13,350$ & $\$ 128,815$ & $\$ 6,744$ & 420 & 79 \\
\hline \multicolumn{10}{|c|}{ Panel B: Central and Eastern Europe } \\
\hline Bulgaria & 4,484 & 6 & 55 & $\$ 3,725$ & $\$ 592$ & $\$ 3,412$ & $\$ 409$ & 248 & 118 \\
\hline Croatia & 1,280 & 1 & 49 & $\$ 17,521$ & $\$ 6,619$ & $\$ 43,278$ & $\$ 11,828$ & 334 & 158 \\
\hline Czechoslovakia & 4,370 & 6 & 54 & $\$ 14,657$ & $\$ 3,868$ & $\$ 15,890$ & $\$ 3,049$ & 257 & 100 \\
\hline Estonia & 2,939 & 1 & 51 & $\$ 2,928$ & $\$ 918$ & $\$ 2,062$ & $\$ 411$ & 81 & 40 \\
\hline Hungary & 2,852 & 7 & 53 & $\$ 24,842$ & $\$ 6,317$ & $\$ 16,924$ & $\$ 3,078$ & 438 & 130 \\
\hline Latvia & 1,326 & 1 & 50 & $\$ 5,277$ & $\$ 1,955$ & $\$ 4,702$ & $\$ 1,086$ & 188 & 100 \\
\hline Lithuania & 336 & 1 & 38 & $\$ 9,646$ & $\$ 3,813$ & $\$ 6,699$ & $\$ 2,165$ & 356 & 127 \\
\hline Macedonia & 35 & 1 & 19 & $\$ 487$ & $\$ 119$ & $\$ 1,424$ & $\$ 890$ & 651 & 339 \\
\hline Poland & 9,338 & 16 & 54 & $\$ 22,968$ & $\$ 6,951$ & $\$ 18,379$ & $\$ 3,675$ & 377 & 148 \\
\hline Romania & 13,762 & 8 & 56 & $\$ 2,940$ & $\$ 636$ & $\$ 2,810$ & $\$ 377$ & 234 & 51 \\
\hline Russia & 9,059 & 1 & 54 & $\$ 41,985$ & $\$ 3,034$ & $\$ 101,929$ & $\$ 5,615$ & 1,105 & 347 \\
\hline Slovakia & 415 & 4 & 48 & $\$ 19,456$ & $\$ 4,531$ & $\$ 20,079$ & $\$ 3,898$ & 353 & 124 \\
\hline Ukraine & 343 & 1 & 44 & . & . & $\$ 24,331$ & $\$ 5,663$ & 532 & 309 \\
\hline Yugoslavia & 296 & 1 & 41 & $\$ 14,362$ & $\$ 3,197$ & $\$ 30,280$ & $\$ 5,985$ & 427 & 186 \\
\hline
\end{tabular}

Note: The first three columns of the table provide the number of firms and regions by country and the number of industries represented within those countries. The next six columns

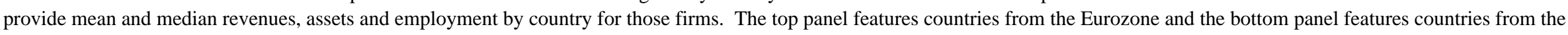
Central and Eastern Europe. The sample is restricted to those firms with more than twenty employees. 
Table 2

\section{Descriptive Statistics by Industry, 1998}

\begin{tabular}{|c|c|c|c|c|c|c|c|c|c|}
\hline Industry & $\begin{array}{l}\text { Number of } \\
\text { Firms }\end{array}$ & $\begin{array}{l}\text { Number of } \\
\text { Countries }\end{array}$ & $\begin{array}{l}\text { Number of } \\
\text { Regions }\end{array}$ & $\begin{array}{c}\text { Mean } \\
\text { Revenues (\$ } \\
\text { thousands) }\end{array}$ & $\begin{array}{c}\text { Median } \\
\text { Revenues (\$ } \\
\text { thousands) }\end{array}$ & $\begin{array}{l}\text { Mean Assets } \\
\text { (\$ thousands) }\end{array}$ & $\begin{array}{c}\text { Median } \\
\text { Assets (\$ } \\
\text { thousands) }\end{array}$ & $\begin{array}{c}\text { Mean } \\
\text { Employment }\end{array}$ & $\begin{array}{c}\text { Median } \\
\text { Employment }\end{array}$ \\
\hline Mining-Coal & 360 & 26 & 85 & $\$ 207,486$ & $\$ 15,353$ & $\$ 368,356$ & $\$ 25,962$ & 2,460 & 403 \\
\hline Oil and Gas Extraction & 3,129 & 29 & 221 & $\$ 179,577$ & $\$ 2,400$ & $\$ 254,009$ & $\$ 2,353$ & 558 & 64 \\
\hline Mining-Uranium & 1,661 & 29 & 172 & $\$ 11,712$ & $\$ 1,379$ & $\$ 7,035$ & $\$ 855$ & 221 & 43 \\
\hline Mining-Metal & 2,803 & 28 & 187 & $\$ 6,271$ & $\$ 1,613$ & $\$ 10,506$ & $\$ 669$ & 145 & 43 \\
\hline Mining-Other & 2,164 & 29 & 239 & $\$ 46,307$ & $\$ 4,859$ & $\$ 99,505$ & $\$ 3,892$ & 275 & 49 \\
\hline Food & 18,326 & 32 & 263 & $\$ 55,931$ & $\$ 7,492$ & $\$ 45,637$ & $\$ 4,881$ & 344 & 82 \\
\hline Tobacco & 232 & 26 & 80 & $\$ 425,501$ & $\$ 34,152$ & $\$ 323,605$ & $\$ 22,390$ & 869 & 280 \\
\hline Textiles-manufacture & 7,377 & 31 & 238 & $\$ 18,620$ & $\$ 6,066$ & $\$ 15,812$ & $\$ 4,772$ & 223 & 70 \\
\hline Clothing & 4,386 & 30 & 228 & $\$ 19,721$ & $\$ 4,000$ & $\$ 18,277$ & $\$ 2,548$ & 226 & 70 \\
\hline Leather & 2,359 & 31 & 195 & $\$ 19,955$ & $\$ 5,363$ & $\$ 13,726$ & $\$ 3,401$ & 214 & 65 \\
\hline Wood & 5,466 & 30 & 241 & $\$ 17,761$ & $\$ 5,399$ & $\$ 17,008$ & $\$ 3,670$ & 173 & 50 \\
\hline Paper & 3,535 & 30 & 233 & $\$ 61,953$ & $\$ 11,443$ & $\$ 71,119$ & $\$ 8,605$ & 305 & 80 \\
\hline Publishing & 9,252 & 32 & 244 & $\$ 37,145$ & $\$ 6,422$ & $\$ 37,673$ & $\$ 4,580$ & 208 & 51 \\
\hline Refined Petroleum & 515 & 28 & 155 & $\$ 550,169$ & $\$ 33,269$ & $\$ 459,250$ & $\$ 29,958$ & 696 & 101 \\
\hline Chemicals & 8,047 & 32 & 251 & $\$ 123,220$ & $\$ 16,677$ & $\$ 138,828$ & $\$ 13,123$ & 1,042 & 89 \\
\hline Rubber & 5,481 & 31 & 246 & $\$ 37,799$ & $\$ 10,628$ & $\$ 35,479$ & $\$ 7,422$ & 319 & 77 \\
\hline Glass, Ceramics & 7,660 & 32 & 251 & $\$ 31,235$ & $\$ 6,819$ & $\$ 39,060$ & $\$ 5,402$ & 291 & 59 \\
\hline Metals-Basic & 4,725 & 31 & 242 & $\$ 90,101$ & $\$ 12,641$ & $\$ 103,791$ & $\$ 9,928$ & 620 & 90 \\
\hline Metals-Fabricated & 20,911 & 31 & 257 & $\$ 16,491$ & $\$ 4,781$ & $\$ 14,322$ & $\$ 3,335$ & 228 & 47 \\
\hline Machinery and Equipment & 16,317 & 31 & 250 & $\$ 49,163$ & $\$ 8,548$ & $\$ 43,631$ & $\$ 6,587$ & 307 & 70 \\
\hline Computers, Office & 1,204 & 25 & 164 & $\$ 103,700$ & $\$ 12,006$ & $\$ 89,705$ & $\$ 8,596$ & 370 & 74 \\
\hline Electrical Machinery & 9,045 & 31 & 248 & $\$ 30,374$ & $\$ 4,563$ & $\$ 27,562$ & $\$ 3,519$ & 221 & 46 \\
\hline Telecommunication- & 3,141 & 29 & 216 & $\$ 95,782$ & $\$ 10,693$ & $\$ 73,364$ & $\$ 7,741$ & 449 & 82 \\
\hline Optical, medical & 4,031 & 31 & 221 & $\$ 64,782$ & $\$ 8,524$ & $\$ 74,735$ & $\$ 8,393$ & 381 & 70 \\
\hline Motor Vehicles- & 3,035 & 29 & 235 & $\$ 313,034$ & $\$ 12,059$ & $\$ 309,375$ & $\$ 8,557$ & 1,331 & 100 \\
\hline Transport-Other & 1,825 & 31 & 213 & $\$ 79,710$ & $\$ 8,957$ & $\$ 102,597$ & $\$ 8,082$ & 1,090 & 99 \\
\hline Furniture & 8,079 & 29 & 247 & $\$ 15,576$ & $\$ 5,382$ & $\$ 10,477$ & $\$ 3,442$ & 138 & 50 \\
\hline Recycling & 568 & 22 & 128 & $\$ 8,729$ & $\$ 3,109$ & $\$ 8,524$ & $\$ 1,973$ & 98 & 42 \\
\hline Electricity, gas, hot water & 2,297 & 29 & 203 & $\$ 275,874$ & $\$ 22,356$ & $\$ 554,410$ & $\$ 46,176$ & 1,924 & 154 \\
\hline Water-Collection and & 680 & 23 & 156 & $\$ 61,082$ & $\$ 5,939$ & $\$ 206,458$ & $\$ 11,936$ & 416 & 117 \\
\hline Construction & 37,311 & 31 & 263 & $\$ 18,745$ & $\$ 3,912$ & $\$ 24,126$ & $\$ 2,606$ & 157 & 42 \\
\hline Motor vehicles-sale,repair & 15,889 & 32 & 259 & $\$ 38,636$ & $\$ 12,502$ & $\$ 19,622$ & $\$ 4,626$ & 97 & 40 \\
\hline Wholesale & 44,714 & 32 & 263 & $\$ 61,956$ & $\$ 11,900$ & $\$ 30,198$ & $\$ 6,025$ & 194 & 44 \\
\hline Retail & 18,661 & 32 & 261 & $\$ 83,475$ & $\$ 7,382$ & $\$ 42,077$ & $\$ 2,706$ & 716 & 43 \\
\hline Hotels and restaurants & 9,211 & 31 & 257 & $\$ 16,643$ & $\$ 2,898$ & $\$ 25,736$ & $\$ 2,316$ & 248 & 46 \\
\hline Land transport & 10,731 & 30 & 253 & $\$ 26,667$ & $\$ 4,384$ & $\$ 50,015$ & $\$ 2,705$ & 338 & 47 \\
\hline Water transport & 808 & 28 & 121 & $\$ 103,553$ & $\$ 15,414$ & $\$ 123,762$ & $\$ 18,005$ & 549 & 120 \\
\hline Air transport & 405 & 28 & 101 & $\$ 323,677$ & $\$ 19,890$ & $\$ 325,729$ & $\$ 17,306$ & 1,412 & 238 \\
\hline Auxiliary transport & 7,162 & 31 & 240 & $\$ 51,196$ & $\$ 9,377$ & $\$ 51,267$ & $\$ 5,326$ & 216 & 56 \\
\hline Postal and & 1,333 & 30 & 170 & $\$ 358,397$ & $\$ 14,125$ & $\$ 523,103$ & $\$ 12,874$ & 2,337 & 112 \\
\hline Financial & 4,504 & 25 & 166 & $\$ 130,636$ & $\$ 7,384$ & $\$ 512,289$ & $\$ 8,923$ & 630 & 65 \\
\hline Auxiliary financial & 1,403 & 26 & 158 & $\$ 197,666$ & $\$ 14,001$ & $\$ 988,963$ & $\$ 21,921$ & 749 & 66 \\
\hline Real estate & 5,210 & 28 & 224 & $\$ 63,858$ & $\$ 8,179$ & $\$ 119,825$ & $\$ 11,265$ & 617 & 48 \\
\hline Renting machinery & 1,335 & 25 & 189 & $\$ 43,078$ & $\$ 7,618$ & $\$ 71,257$ & $\$ 7,311$ & 179 & 42 \\
\hline Computer-services & 6,470 & 30 & 215 & $\$ 39,241$ & $\$ 6,893$ & $\$ 22,120$ & $\$ 4,122$ & 199 & 49 \\
\hline Research and Development & 1,027 & 27 & 163 & $\$ 20,399$ & $\$ 4,546$ & $\$ 34,512$ & $\$ 6,079$ & 309 & 138 \\
\hline Other Business Activities & 26,774 & 32 & 254 & $\$ 63,868$ & $\$ 5,863$ & $\$ 79,469$ & $\$ 4,212$ & 433 & 63 \\
\hline Public Administration & 208 & 19 & 75 & $\$ 20,222$ & $\$ 1,873$ & $\$ 27,462$ & $\$ 812$ & 453 & 64 \\
\hline Education & 1,992 & 26 & 187 & $\$ 8,420$ & $\$ 3,117$ & $\$ 10,418$ & $\$ 2,392$ & 136 & 58 \\
\hline Health and social work & 6,273 & 27 & 224 & $\$ 14,181$ & $\$ 3,645$ & $\$ 10,620$ & $\$ 2,436$ & 218 & 68 \\
\hline Sewage and sanitation & 1,992 & 27 & 214 & $\$ 17,637$ & $\$ 4,111$ & $\$ 28,718$ & $\$ 2,303$ & 173 & 58 \\
\hline Professional organizations & 364 & 19 & 94 & $\$ 26,270$ & $\$ 4,440$ & $\$ 30,793$ & $\$ 4,181$ & 138 & 42 \\
\hline Recreation, cultural & 3,557 & 31 & 232 & $\$ 40,637$ & $\$ 5,138$ & $\$ 36,886$ & $\$ 4,371$ & 281 & 53 \\
\hline Other services & 3,115 & 25 & 206 & $\$ 4,809$ & $\$ 2,557$ & $\$ 4,249$ & $\$ 1,956$ & 74 & 42 \\
\hline Private households & 5 & 3 & 5 & $\$ 2,718$ & $\$ 1,479$ & $\$ 3,758$ & $\$ 2,331$ & 59 & 37 \\
\hline Missing & 24,943 & 31 & 230 & $\$ 13,444$ & $\$ 3,523$ & $\$ 20,217$ & $\$ 2,535$ & 213 & 36 \\
\hline
\end{tabular}

Note: The first three columns of the table provide the number of firms and countries by industry and the number of regions represented within those industries. The next six columns provide mean and median revenues, assets and employment by country for those firms. The sample is restricted to those firms with more than twenty employees. 
Table 3

Determinants of Entry in Europe, 1998

Dependent Variable: Rate of Entry, 1998

OLS Univariates

All europe

(1)

(2)

Fairness Index

$-0.7370$

(1.0179)

1518

$-0.4610$

(0.7774)

1518

Formalism Index

2.8788

(4.8328)

3.4709

(5.4512)

1468

1468

Interference of Courts

$-0.1070^{* * *}$

(0.0207)

$-0.1021^{* * *}$

(0.0199)

863

863

Start up Procedures

$$
1.5289
$$

1396

1.6259

(1.3797)

1396

Protection of Property

Rights

$\begin{array}{rc}-5.2522 & -3.6880 \\ (5.3976) & (4.0308) \\ 1213 & 1213\end{array}$

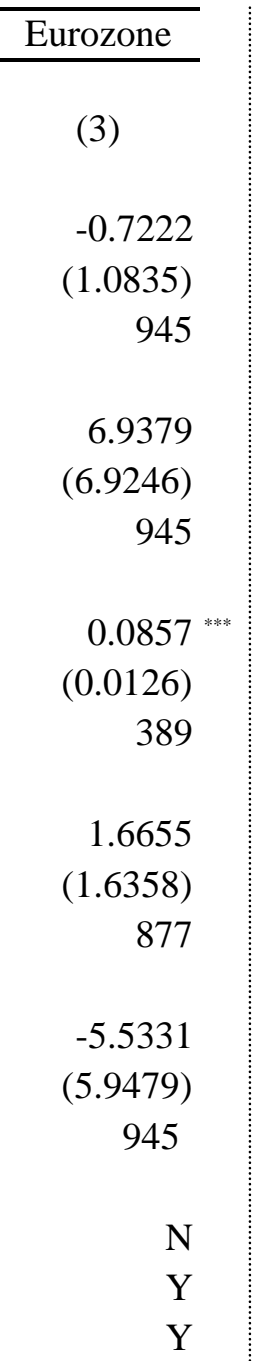

Median Univariates

\begin{tabular}{|c|c|c|c|}
\hline \multicolumn{4}{|c|}{ Median Univariates } \\
\hline \multicolumn{2}{|c|}{ All europe } & Eurozone & $\mathrm{CEE}$ \\
\hline (1) & (2) & (3) & (4) \\
\hline 0.0007 & 0.0013 & -0.0033 & $0.0543^{* * *}$ \\
\hline$(0.0042)$ & $(0.0033)$ & $(0.0022)$ & $(0.0203)$ \\
\hline 1518 & 1518 & 945 & 573 \\
\hline 0.0051 & 0.0046 & $0.0368^{* * *}$ & $-0.2590^{* * *}$ \\
\hline$(0.0125)$ & (0.0095) & $(0.0066)$ & $(0.0567)$ \\
\hline 1468 & 1468 & 945 & 523 \\
\hline-0.0168 & -0.0190 & $0.0562^{* * *}$ & $-0.2881^{* * *}$ \\
\hline$(0.0160)$ & $(0.0246)$ & $(0.0131)$ & $(0.0463)$ \\
\hline 863 & 863 & 389 & 474 \\
\hline $0.0073^{* * *}$ & $0.0074^{* * *}$ & $0.0055^{* * *}$ & $0.0395^{* * *}$ \\
\hline$(0.0014)$ & 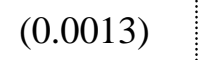 & $(0.0012)$ & $(0.0128)$ \\
\hline 1396 & 1396 & 877 & 519 \\
\hline $0.0272^{* * *}$ & $0.0349^{* * *}$ & 0.0122 & $0.2717^{* * *}$ \\
\hline$(0.0087)$ & (0.0105) & $(0.0125)$ & $(0.0390)$ \\
\hline 1213 & 1213 & 945 & 268 \\
\hline $\mathrm{N}$ & $\mathrm{Y}^{* *}$ & $\mathrm{~N}$ & $\mathrm{~N}$ \\
\hline $\mathrm{Y}$ & $\mathrm{Y}$ & $\mathrm{Y}$ & $\mathrm{Y}$ \\
\hline $\mathrm{Y}$ & $\mathrm{Y}$ & $\mathrm{Y}$ & $\mathrm{Y}$ \\
\hline
\end{tabular}

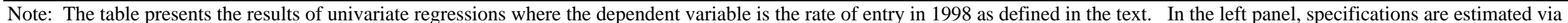

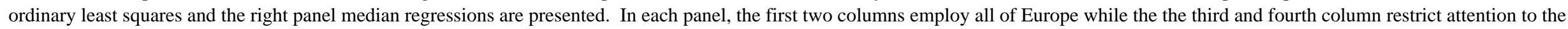

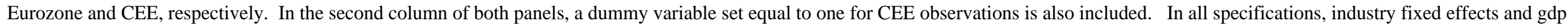

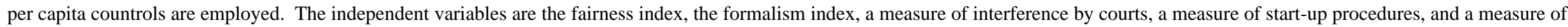

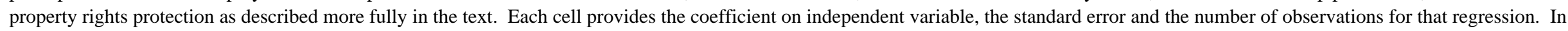
OLS specifications, the standard errors are heteroskedastiictv-consistent and in the median regressions, standard errors are bootstrapped. 
Table 4

Determinants of Exit in Europe, 1998

Dependent Variable: Rate of Exit, 1998

OLS Univariates

All europe

(1)

(2)

Fairness Index

Formalism Index

$-0.0155$

(0.0035)

1409

$-0.0131^{*+*+4}$

(0.0031)

1409

$0.0151^{* *}$

(0.0043)

1369

$0.0154^{*+4+\infty}$

(0.0046)

1369

Interference of Courts

$-0.0357^{* *}$
$(0.0162)$

784

$-0.0287^{*}$

(0.0171)

784

Start up Procedures

0.0050 **
$(0.0013)$
1296

Protection of Property

Rights

$\begin{array}{cr}-0.0411^{* * *} & -0.0241^{* * *} \\ (0.0084) & (0.0069) \\ 1169 & 1169\end{array}$

1169

1169

$\begin{array}{ll}N & Y \\ Y & Y \\ Y & Y\end{array}$

CEE dummy?

Industry Fixed Effects?

GDP per capita controls?
Median Univariates

\begin{tabular}{|c|c|c|c|}
\hline \multicolumn{4}{|c|}{ Median Univariates } \\
\hline \multicolumn{2}{|c|}{ All europe } & Eurozone & CEE \\
\hline (1) & (2) & (3) & (4) \\
\hline$-0.0057^{* * *}$ & $-0.0062^{* *+*}$ & $-0.0079^{* * * *}$ & $-0.0323^{* * *}$ \\
\hline$(0.0018)$ & $(0.0019)$ & $(0.0014)$ & $(0.0058)$ \\
\hline 1409 & 1409 & 913 & 496 \\
\hline 0.0029 & $0.0037^{* *}$ & $0.0097^{* * * *}$ & -0.0009 \\
\hline$(0.0029)$ & (0.0018) & $(0.0026)$ & $(0.0072)$ \\
\hline 1369 & 1369 & 913 & 456 \\
\hline$-0.0133^{* *}$ & $-0.0140^{* *}$ & -0.0030 & $0.0672^{* * *}$ \\
\hline$(0.0063)$ & (0.0068) & $(0.0069)$ & $(0.0173)$ \\
\hline 784 & 784 & 381 & 403 \\
\hline$-0.0030^{* * *}$ & $0.0030^{*+*+*}$ & $0.0033^{* * * *}$ & 0.0035 \\
\hline$(0.0006)$ & $(0.0005)$ & $(0.0005)$ & $(0.0034)$ \\
\hline 1296 & 1296 & 852 & 444 \\
\hline$-0.0106 * *$ & -0.0134 & $-0.0106^{*}$ & $-0.0530^{* * *}$ \\
\hline$(0.0036)$ & $(0.0052)$ & $(0.0055)$ & $(0.0063)$ \\
\hline 1169 & 1169 & 913 & 256 \\
\hline $\mathrm{N}$ & $\mathrm{Y}$ & $\mathrm{N}$ & $\mathrm{N}$ \\
\hline $\mathrm{Y}$ & $\mathrm{Y}$ & $\mathrm{Y}$ & $\mathrm{Y}$ \\
\hline $\mathrm{Y}$ & $\mathrm{Y}$ & $\mathrm{Y}$ & $\mathrm{Y}$ \\
\hline
\end{tabular}

$\begin{array}{r}\hline \text { Eurozone } \\ \hline(3) \\ \hline-0.0042^{* *} \\ (0.0020) \\ 913 \\ 0.0184^{* * *} \\ (0.0047) \\ 913 \\ 0.0173^{* * *} \\ (0.0061) \\ 381 \\ -0.0002 \\ (0.0012) \\ 852 \\ 0.0032 \\ (0.0068) \\ 913 \\ \mathrm{~N} \\ \mathrm{Y} \\ \mathrm{Y} \\ \hline\end{array}$

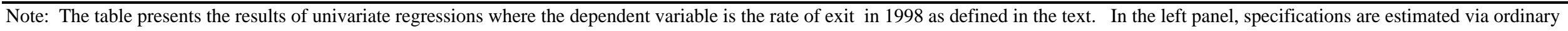

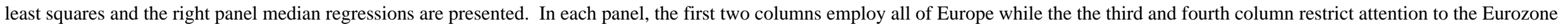

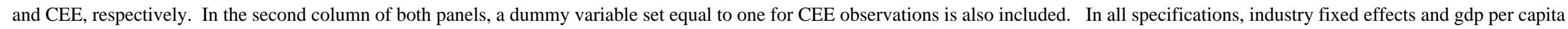

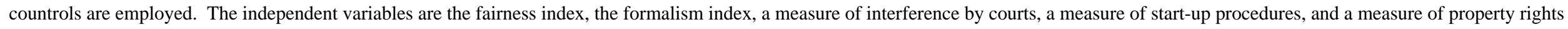

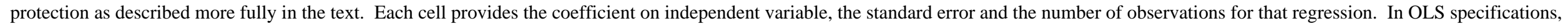
the standard errors are heteroskedastiictv-consistent and in the median regressions. standard errors are bootstrapbed.
} 
Table 5

\section{Determinants of Size in Europe, 1998}

Dependent Variable: Average Firm Size, 1998

OLS Univariates

$\overline{\text { All europe }}$

(1)

(2)

Fairness Index

$\begin{array}{cc}-0.0570 * * & -0.0288 * \\ (0.0189) & (0.0167) \\ 1523 & 1523\end{array}$

Formalism Index

$\begin{array}{cc}-0.3514^{* *} & -0.2966^{* *} \\ (0.0328) & (0.0331) \\ 1475 & 1475\end{array}$

Interference of Courts

$\begin{array}{rr}0.3530 & * * \\ (0.0634) & 0.3985^{* *} \\ 889 & 8.0636) \\ & 889\end{array}$

Start up Procedures

$\begin{array}{rr}0.0194^{* * *} & 0.0204 \\ (0.0065) & (0.0063) \\ 1411 & 1411\end{array}$

Protection of Property

Rights

$\begin{array}{cr}-0.3636^{* * *} & -0.2027^{* *+} \\ (0.0426) & (0.0413) \\ 1279 & 1279\end{array}$

\begin{tabular}{r}
\hline Euroz \\
(3)
\end{tabular}

CEE dummy?

Industry Fixed Effects?

GDP per capita controls?

$\begin{array}{ll}\mathrm{N} & \mathrm{Y} \\ \mathrm{Y} & \mathrm{Y} \\ \mathrm{Y} & \mathrm{Y}\end{array}$

\begin{tabular}{|c|c|c|c|}
\hline \multicolumn{4}{|c|}{ Median Univariates } \\
\hline \multicolumn{2}{|c|}{ All europe } & Eurozone & $\mathrm{CEE}$ \\
\hline (1) & $(2)$ & (3) & (4) \\
\hline 0.0015 & 0.0171 & $0.0388^{* * * *}$ & $-0.3017^{* * *}$ \\
\hline$(0.0161)$ & $(0.0105)$ & (0.0128) & $(0.0508)$ \\
\hline 1523 & 1523 & 918 & 605 \\
\hline$-0.4284 * *$ & $-0.3413^{* * *}$ & $-0.1239 * *$ & $-0.8545^{* * *}$ \\
\hline$(0.0280)$ & $(0.0392)$ & $(0.0505)$ & $(0.0895)$ \\
\hline 1475 & 1475 & 918 & 557 \\
\hline $0.2893^{* * *}$ & $0.3061^{* * * 1}$ & $0.1114^{* * *}$ & $0.7154^{* * *}$ \\
\hline$(0.0937)$ & $(0.0865)$ & $(0.0344)$ & $(0.1426)$ \\
\hline 889 & 889 & 383 & 506 \\
\hline 0.0011 & 0.0021 & -0.0064 & $0.0873^{* * *}$ \\
\hline$(0.0048)$ & $(0.0037)$ & $(0.0044)$ & $(0.0167)$ \\
\hline 1411 & 1411 & 857 & 554 \\
\hline$-0.2384^{* * *}$ & -0.0807 & 0.0955 & $-0.3175^{* * *}$ \\
\hline$(0.0592)$ & $(0.0544)$ & $(0.0367)$ & $(0.0717)$ \\
\hline 1279 & 1279 & 918 & 361 \\
\hline $\mathrm{N}$ & $\mathrm{Y}$ & $\mathrm{N}$ & $\mathrm{N}$ \\
\hline $\mathrm{Y}$ & $\mathrm{Y}$ & $\mathrm{Y}$ & $\mathrm{Y}$ \\
\hline $\mathrm{Y}$ & $\mathrm{Y}$ & $\mathrm{Y}$ & $\mathrm{Y}$ \\
\hline
\end{tabular}

$0.0585^{* * *}$

(0.0147)

918

$-0.0580 *$

(0.0336)

918

0.1390 **

(0.0562)

383

$-0.0048$

(0.0062)

857

0.0787

(0.0485)

918
(3) (4)

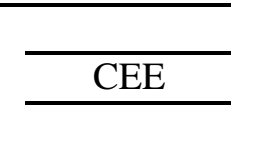
$-0.2980$
(0.0407)$$
605
$$

$-0.8830^{* * *}$

(0.0638)

557

$0.6596^{* * *+}$

(0.1112)

506

$0.1214^{* * *}$

(0.0137)

554

$-0.3199^{* * * *}$

(0.0651)

361

$\mathrm{N}$
$\mathrm{Y}$
$\mathrm{Y}$

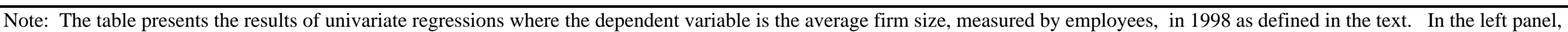

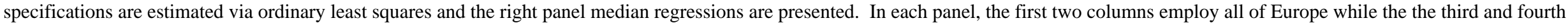

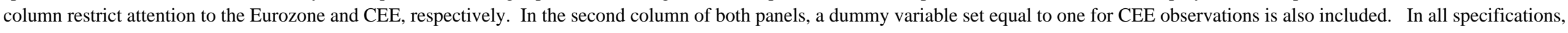

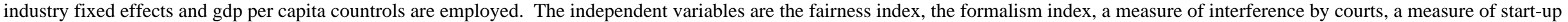

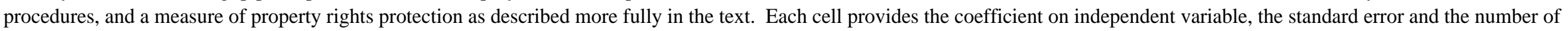
observations for that regression. In OLS specifications, the standard errors are heteroskedastiicty-consistent and in the median regressions, standard errors are bootstrapped. 
Table 6

Determinants of Vintage in Europe, 1998

Dependent Variable: Vintage, 1998

OLS Univariates

All europe

(1)

(2)

Fairness Index

Formalism Index

Interference of Courts

$0.5833^{* * *}$

(0.0572)

888

(0.0533)

888

Start up Procedures

$\begin{array}{rr}0.0145^{* *} & 0.0130^{* *} \\ (0.0057) & (0.0057) \\ 1409 & 1409 \\ & \\ 0.1386 \text { *** } & -0.0648^{*} \\ (0.0430) & (0.0389) \\ 1272 & 1272\end{array}$

Protection of Property

Rights

CEE dummy

Industry Fixed Effects?

GDP per capital controls?
Median Univariates

\begin{tabular}{|c|c|c|c|}
\hline \multicolumn{2}{|c|}{ All europe } & Eurozone & CEE \\
\hline (1) & (2) & (3) & (4) \\
\hline $0.0832^{* * *}$ & $0.0541^{* * * * x}$ & 0.0374 * & 0.1123 * \\
\hline$(0.0133)$ & $(0.0182)$ & $(0.0207)$ & $(0.0403)$ \\
\hline 1516 & 1516 & 912 & 604 \\
\hline-0.0354 & -0.1439 & $-0.1582^{* * *}$ & 0.0574 \\
\hline$(0.0421)$ & (0.0509) & $(0.0396)$ & $(0.0980)$ \\
\hline 1468 & 1468 & 912 & 556 \\
\hline $0.3799^{* * *}$ & $0.3452^{* * *+4}$ & $-0.1370^{* *}$ & 0.4185 * \\
\hline$(0.0950)$ & $(0.1005)$ & $(0.0652)$ & $(0.1499)$ \\
\hline 888 & 888 & 383 & 505 \\
\hline $0.0110^{*}$ & 0.0129 & 0.0088 & 0.0597 \\
\hline$(0.0066)$ & $(0.0038)$ & $(0.0061)$ & (0.0179) \\
\hline 1409 & 1409 & 856 & 553 \\
\hline $0.1795^{* * *}$ & -0.0578 & 0.0497 & 0.0057 \\
\hline$(0.0547)$ & $(0.0598)$ & $(0.0522)$ & $(0.1125)$ \\
\hline 1272 & 1272 & 912 & 360 \\
\hline $\mathrm{N}$ & $\mathrm{Y}$ & $\mathrm{N}$ & $\mathrm{N}$ \\
\hline $\mathrm{Y}$ & $\mathrm{Y}$ & $\mathrm{Y}$ & $\mathrm{Y}$ \\
\hline $\mathrm{Y}$ & $\mathrm{Y}$ & $\mathrm{Y}$ & $\mathrm{Y}$ \\
\hline
\end{tabular}

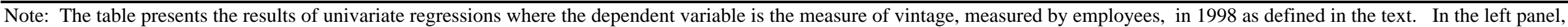

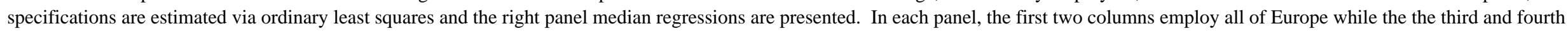

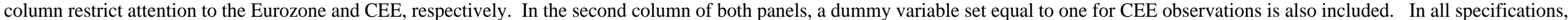

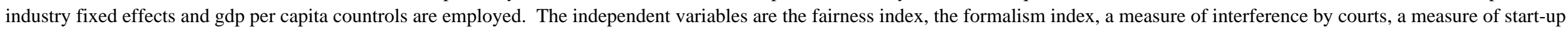

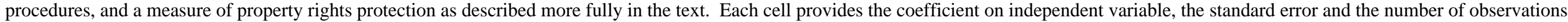
for that regression. In OLS specifications, the standard errors are heteroskedastiicty-consistent and in the median regressions, standard errors are bootstrapped. 
Table 7

Determinants of Skewness in Europe, 1998

Dependent Variable: Skewness, 1998

OLS Univariates

$\overline{\text { All europe }}$

(1)

$-0.0261$

(0.0163)

1396

(2)

Fairness Index

Formalism Index

0.1128 ***

$-0.0377^{*}$

(0.0159)

1396

(0.0309)

1361

0.0804

(0.0326)

1361

0.0561

$-0.0002$

Interference of Courts

(0.0610)

823

(0.0589)

$$
823
$$

$-0.0045$

(0.0059)

$-0.0056$

Start up Procedures

1319

(0.0059)

1319

$-0.0597$

(0.0394)

1183
$-0.1611^{* * *}$
(0.0409)
1183

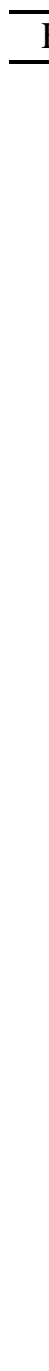

Median Univariates

\begin{tabular}{|c|c|c|c|}
\hline \multicolumn{4}{|c|}{ Median Univariates } \\
\hline \multicolumn{2}{|c|}{ All europe } & Eurozone & CEE \\
\hline (1) & (2) & (3) & (4) \\
\hline-0.0036 & -0.0048 & 0.0171 & -0.139298 ** \\
\hline (0.0184) & $(0.0142)$ & $(0.0141)$ & $(0.0602)$ \\
\hline 1396 & 1396 & 858 & 538 \\
\hline $0.1348^{* * *}$ & 0.0725 & $0.1089^{* *}$ & 0.1648 * \\
\hline$(0.0265)$ & $(0.0514)$ & $(0.0535)$ & $(0.0900)$ \\
\hline 1361 & 1361 & 858 & 503 \\
\hline 0.0076 & -0.0118 & $-0.4374^{* * *}$ & 0.1636 \\
\hline (0.0749) & $(0.0637)$ & $(0.0534)$ & (0.1249) \\
\hline 823 & 823 & 374 & 449 \\
\hline-0.0023 & -0.0049 & $-0.0157^{* * * *}$ & 0.0762 ** \\
\hline$(0.0046)$ & $(0.0056)$ & $(0.0061)$ & $(0.0126)$ \\
\hline 1319 & 1319 & 825 & 494 \\
\hline$-0.0649^{*}$ & $-0.1827^{*+*}$ & -0.0232 & -0.2808 ** \\
\hline (0.0359) & (0.0250) & $(0.0612)$ & $(0.0853)$ \\
\hline 1183 & 1183 & 858 & 325 \\
\hline $\mathrm{N}$ & $\mathrm{Y}$ & $\mathrm{N}$ & $\mathrm{N}$ \\
\hline $\mathrm{Y}$ & $\mathrm{Y}$ & $\mathrm{Y}$ & $\mathrm{Y}$ \\
\hline $\mathrm{Y}$ & $\mathrm{Y}$ & $\mathrm{Y}$ & $\mathrm{Y}$ \\
\hline
\end{tabular}

Note: The table presents the results of univariate regressions where the dependent variable is the skewness of the firm-size distribution in 1998 as defined in the text. In the left panel, specifications are estimated via ordinary least squares and the right panel median regressions are presented. In each panel, the first two columns employ all of Europe while the the third and fourth column restrict attention to the Eurozone and CEE, respectively. In the second column of both panels, a dummy variable set equal to one for CEE observations is also included. In all specifications, industry fixed effects and gdp per capita countrols are employed. The independent variables are the fairness index, the formalism index, a measure of interference by courts, a measure of start-up procedures, and a measure of property rights protection as described more fully in the text. Each cell provides the coefficient on independent variable, the standard error and the number of observations for that regression. In OLS specifications, the standard errors are heteroskedastiicty-consistent and in the median regressions, standard errors are bootstrapped. 
Table 8

Determinants of Differential Skewness in Europe, 1998

Dependent Variable: Skewness (Below the Median Age - Above the Median Age), 1998

OLS Univariates

All europe
(1)

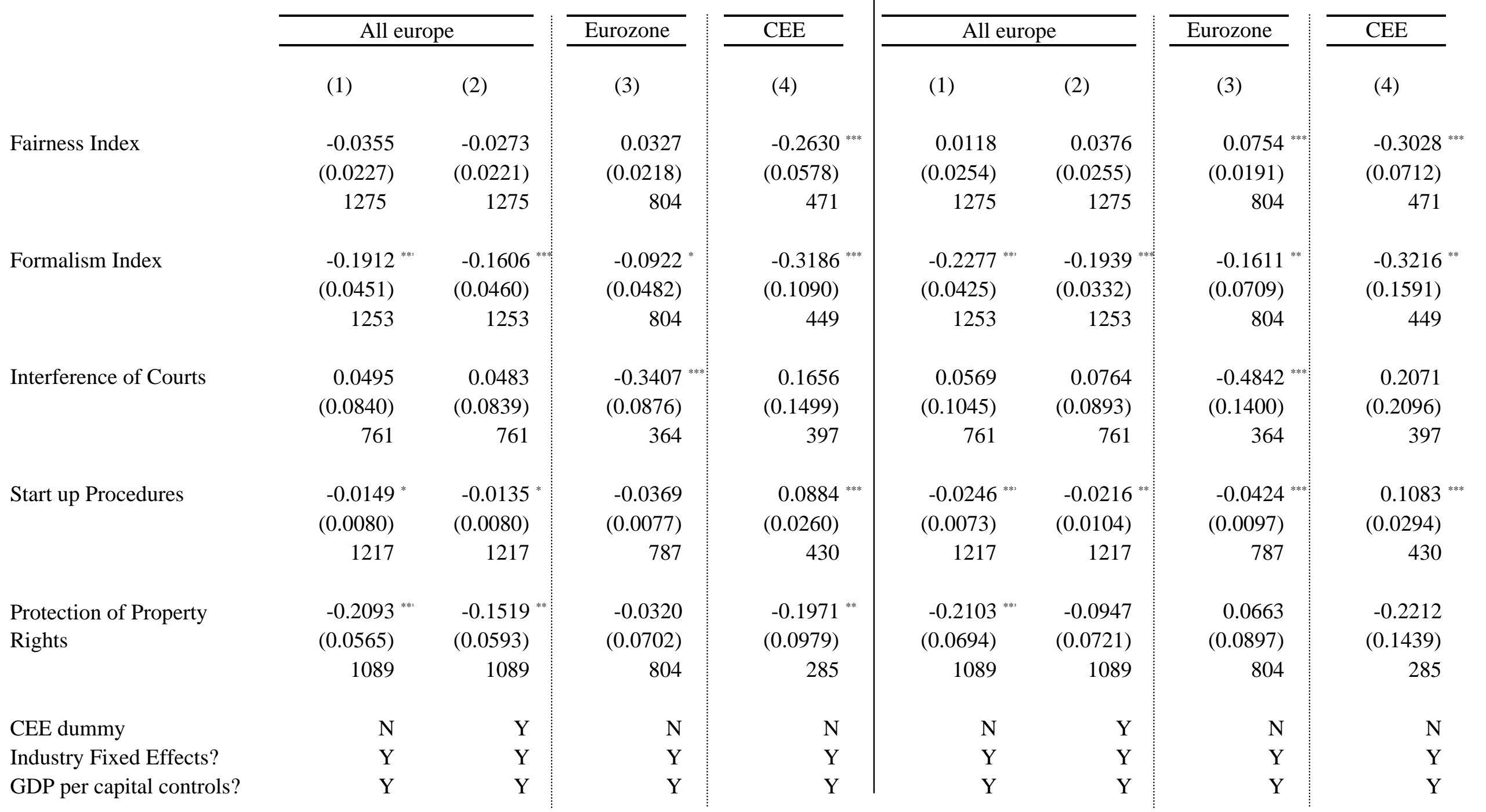

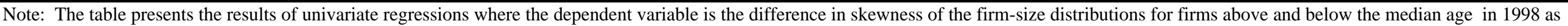

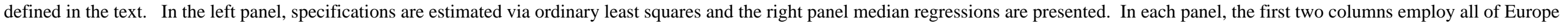

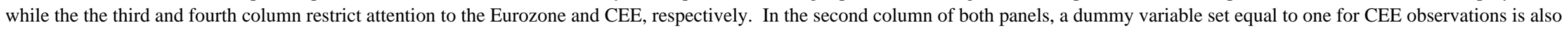

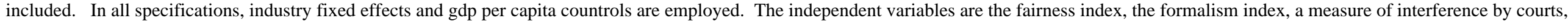

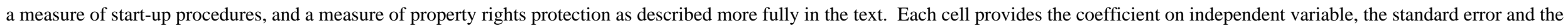
number of observations for that regression. In OLS specifications, the standard errors are heteroskedastiicty-consistent and in the median regressions, standard errors are bootstrapped.
Median Univariates 